\title{
O NINHO DA ÁGUIA. NAPOLEÃO E SUA POLÍTICA DE LUGARES: PARIS COMO CENTRO DO MUNDO'
}

\author{
Raquel Stoiani \\ Mestre em História - FFLCH/USP
}

\section{Resumo}

Neste artigo analisamos como Napoleão Bonaparte marcou simbolicamente espaços públicos e privados, com fins de legitimação política, interferindo na ordenação das cidades, em especial da cidade de Paris, formando um cenário para seu poder. Para tanto, destacamos alguns monumentos, no que chamamos de topografia simbólica.

\section{Abstract}

In this article we analyze how Napoleon Bonaparte signed symbolically the public and the private spaces, with the purpose of politic legitimation, interfering in the arrangement of cities, Paris especially, constituting a scenery to his power. In such a way, we distinguish some monuments, from that we designate as symbolical topography.

\section{Pallavras-Chave}

Napoleão Bonaparte • Paris • França (século XIX) • Primeiro Império Francês • Monumentos

\section{Keywords}

Napoleon Bonaparte $\bullet$ Paris $\bullet$ France $\left(19^{\text {th }}\right.$ century $) \cdot$ French First Empire $\bullet$ Monuments

\footnotetext{
${ }^{1}$ A versão integral deste texto encontra-se na dissertação de mestrado Da Espada à Águia: Construção Simbólica do Poder e Legitimação Política de Napoleão Bonaparte, defendida, em maio de 2002, no programa de Pós-Graduação, na área de História Social, FFLCH - USP.
} 


\section{A Retórica do Poder na Cidade}

"(...) the city which we see and the city which we interpret and the city which we project beyond itself is never the city that is actually there. Ours is more beautiful and simpler and perhaps even more symbolic."

(Buchard 1966: 241)

Dentro do processo de construção simbólica do poder, a cidade tem seu significado expandido ao ser pensada como discurso político que se faz visível através de suas ruas e edifícios. Assim, em última instância, a água que jorra da fonte discursa sobre quem mandou construí-la; a estátua da praça parece cantar, como um bardo, os acontecimentos que ali se sucederam; o cume da alta construção aponta para o céu, denunciando a tamanha pretensão daquele que a decidiu erigir... Passamos a enxergar como o poder marcou-a com seus signos, interferindo em sua ordenação e na utilização de seus espaços.

Portanto, para além de um mero conjunto de sítios e edificações, a cidade constitui-se num conjunto de locais aos quais são atribuídos funções simbólicas. Lugares estes que se convertem em “teatros onde se apresenta a sociedade 'oficial' e, inversamente em que se 'manifesta' o protesto popular" (Balandier 1982: 11-12), cenários para a exaltação do poder ou para sua contestação. Cada monumento, comemoração ou manifestação inscritos em sua topografia - que, como veremos, acabam por apresentar implicações sociais, políticas e econômicas - formam um cenário para o exercício simbólico do poder, concretizando visualmente uma ideologia. Quanto mais grandioso este exercício, mais "torna os espectadores anões para que tomem maior consciência do poder do governante" (Burke 1994: 211). Tais cenários apresentam vários estratos históricos que, analisados dentro de uma arqueologia urbana da comunicação do poder, revelam símbolos e significações depositados e sobrepostos ao longo de sua idade por sucessivos governos através de um jogo de construções e desconstruções que contrapõem, justapõem e compõem tempos e espaços. 
Podemos falar, pois, da existência de uma "topografia simbólica", visto que a cidade é modelada e interpretada segundo uma "política de lugares" que é regida pelas necessidades estratégicas e simbólicas de quem a governa, traduzindo visualmente sua concepção de poder ${ }^{2}$. Nesta topografia transparece tanto o caráter de imortalidade que os monumentos e construções emprestam ao governante - formando seu "esqueleto petrificado" (Apostolidès 1993: 78) e encaixando-o em um quadro competitivo de grandiosidade e monumentalidade, quanto sua movimentação e de seus signos nos espaços públicos e privados, onde o governante se embrenha, muitas vezes com bastante sutileza, no cotidiano dos citadinos cercando-os com sua presença (ainda que possa haver sua ausência física) e sendo interiorizado como um modelo fascinante que se deve seguir e como uma lei que se deve respeitar ${ }^{3}$.

\footnotetext{
${ }^{2}$ As duas expressões são usadas por Balandier. Sobre a expressão "política de lugares" queremos deixar claro que não se trata necessariamente de um programa político pré-estabelecido de reformas da cidade mas, em muitos casos, apenas do conjunto de reformas feitas por um determinado governo.

${ }^{3}$ Eis um exemplo deste tipo de competitividade no século XX, matizado por um espírito de ostentação chauvinista: "Embora a reconstrução de Londres já estivesse completa bem antes da I Guerra Mundi$\mathrm{al}$, as capitais de outros poderes novos ou recentemente afirmados estavam constantemente sendo reconstruídas, para melhor traduzir a grandeza nacional. Na Itália, por exemplo, Mussolini desejava que Roma 'parecesse maravilhosa aos olhos do mundo - vasta, pacífica, poderosa como na época do Império de Augusto', e o Plano-Mestre de 1931 tinha como principal objetivo a criação de uma capital grandiosa e monumental, incluindo a construção da Piazza Venezia, e as grandes e monumentais estradas de acesso da cidade, como a Via Dell'Imperio, que levava ao Coliseu. Também na Alemanha os edifícios imensos, monumentais e descomunais do terceiro Reich, resultado da colaboração entre Hitler e Albert Speer, refletiam um objetivo semelhante. A casa da Arte Alemã, a Chancelaria de Berlim e os edifícios e áreas de desfile de Nuremberg, e os planos posteriores e não realizados de construção de vias e arcos comemorativos em Berlim, refletiam a crença eterna de Hitler de que uma civilização era avaliada pelos grandes edifícios que dela restassem. Este neoclassicismo inovador não se limitou às potências fascistas. Em Moscou, a construção da Praça Vermelha para servir de centro de cerimoniais pode ser considerada parte de uma expressão semelhante, assim como foi o imponente (e não realizado) plano do Palácio dos Sovietes, num prodigioso estilo neoclássico. Em Washington, o término do Lincoln Memorial, a construção do Monumento a Jefferson na Ponte Arlington, assim como de um aglomerado de edifícios administrativos na Avenida da Constituição demonstraram a força da mesma influência exercida do outro lado do Atlântico" (Cannadine 1997: 155-6).
} 


\section{Napoleão e sua Política de Lugares: Paris como Centro do Mundo}

"La nation elle-même n'a dans son caractère et ses goût que du provisoire et du gaspillage. Tout pour le moment et le caprice, rien pour la durée...(...).

J'ai souvent combattu des fêtes que la ville de Paris voulait me donner; c'étaient des dîners, des bals, des feux d'artifice de quatre, de six, de huit cent mille francs, dont les préparatifs obstruaient plusieurs jours [la voie public] et qui coûtaient ensuite autant à defaire qu'ils avaient coûté à construire. Je prouvais qu'avec ces faux frais ils auraient fait des monuments durables, magnifiques..."

(Napoleão apud Las Cases 1951: II, 121)

Como outros tantos homens públicos que marcaram época, Napoleão não escapou aos anseios e à necessidade de se eternizar. Promovendo desde o Consulado várias modificações na textura urbana parisiense e de outras cidades sob domínio francês, inscreveu em pedra seu poder e suas realizações, em um discurso visual silencioso, mas nem por isso menos ambicioso. A exemplo do símbolo-mor de seu poder - a águia -, ele construiu sobre os escombros da Bastilha e de Versalhes seu "ninho", buscando criar sua própria cenografia política.

Guiado, sem dúvida alguma, por um sentimento de rivalidade espacial e temporal, ele converteu muitas das cidades sob sua influência, em especial Paris, em campos de embate onde, por meio do luxo e da monumentalidade, tentou suplantar outros governantes, contemporâneos ou não (incluindo-se aí, mesmo os que estavam por vir), criando uma competição e se definindo por contraste a eles ${ }^{4}$. A cidade é, mais uma

\footnotetext{
${ }^{4}$ Louis Hautecoeur confirma a supremacia de Paris no interior da política napoleônica de lugares: "En province l'activité de la construction fut assez faible 'l'architecture semble maintenant d'une grande faiblesse hors de Paris', écrivait Le Breton dans son Rapport sur les Beaux-Arts en 1808" (Hautecoeur 1953: 28). Desta maneira, vamos adotar a capital parisiense como o grande exemplo de como Napoleão procurou ordenar e utilizar os espaços públicos, marcando-os simbolicamente com seu poder. Um caso exemplar deste tipo de "disputa", anterior a Napoleão, está no esforço empreendido pelos artistas a serviço de Luís XIV para transformar a cidade de Paris em uma nova Roma. Esta tentativa de romanização permitiu-lhe consolidar seu poder ao se afirmar e se legitimar como herdeiro presuntivo desta Antigüidade. Tratava-se de um dispositivo ideológico caro ao Rei-Sol que, ao promover a identificação de seu governo com o Imperium Romanum (visível também na promoção de um mimetismo
} 
vez, tomada como lugar em que o tempo e o espectro de grandes homens disputam e discutem a supremacia da lembrança em busca de eternização e legitimidade.

Napoleão deparou-se com uma Paris de pouco mais de meio milhão de habitantes que se "l'on excepte le quartier de la place Vendôme et les faubourgs Saint-Germain et Saint-Honoré, (...) demeurait encore une ville médiévale, dont les rues étroites tressaient leur labyrinthe parmie les oasis des jardins monacaux" (Hautecoeur 1953: 26). Além de certamente parecer-lhe um cenário pouco digno de seus feitos e de seu poder, fazia-se necessário prosseguir com uma tradição de construção há muito utilizada por outros monarcas. Assim, o restabelecimento do cargo de "Premier Architecte” em favor de Pierre-François-Léonard Fontaine (1762-1853), que viria a ser oficializado como tal apenas em 1813, confirmava sua importância, na mesma linha do chamado "Intendente de Artes", seu equivalente nas cortes de outrora. Por sua vez, a instituição de um “Département de Ponts et Chaussés”, contando especificamente com um “directeur des travaux de Paris" encarregado dos assuntos de reformas e construções nesta cidade, seria a grande engrenagem estatal que auxiliaria Napoleão, desde o Consulado, na retomada do ritmo de construções que havia sido drasticamente abalado com a Revolução Francesa, e na execução de alguns projetos datados, inclusive, da época da Convenção e do Diretório. Em Santa Helena, ouvimolo nostalgicamente evocar seus planos para a capital da França:

"Fazia parte de meus sonhos habituais fazer dela [Paris] a verdadeira capital da Europa, algumas vezes eu quis que ela se tornasse uma cidade de dois, três ou

político que o fazia, antes de ser Luís, o Grande, ser Luís Augusto) procurava se impor devidamente sobre uma pluralidade feudal ainda existente. Se ele precisava ser Luís Augusto, por referência a um tempo mítico, sua cidade-capital deveria constituir-se igualmente num espaço mítico que associava o presente ao passado, auxiliando-o na cristalização de seu retrato mitificado. As aparências romanas que tomavam conta das artes, da literatura e da música, apresentando-se também nos teatros e nas festas da corte, passaram deste modo a marcar a capital da França através da construção ou reforma de igrejas, estátuas, palácios e arcos que testemunhavam os triunfos de "Luís-Augusto". Assim, através de várias reformulações urbanas e arquitetônicas, o rei transferiu simbolicamente a Roma Antiga para Paris, fazendo de sua cidade-capital um sintoma da transfusão da romanidade no corpo da monarquia francesa para dar-lhe novo vigor político (Cf Apostolidès 1993, em especial as pp. 78-9). 
quatro milhões de habitantes, por exemplo; em resumo, algo fabuloso, colossal, desconhecido até nossos dias (...).” (Las Cases 1951/ 2: 120)

O uso de referências clássicas, atualizado e reforçado pelo Neoclassicismo de David desde a época da Convenção, também marcaria o embelezamento das cidades sob Napoleão, estabelecendo propositadamente uma imaginária linha de continuidade com o passado. A utilização destes modelos estéticos clássicos que já haviam expressado a grandiloqüência revolucionária e agora expressavam as ambições imperiais de Napoleão por meio de uma monumentalidade arquitetônica (e David e muitos outros artistas são seus portadores de uma época à outra) ao mesmo tempo em que revela a importância do uso da Antigüidade na busca da legitimidade do poder, também traz aos contemporâneos, através daquela ponte imaginária que parece atravessar diretamente os séculos sem interrupções, os exemplos de civismo, lealdade e sacrifício a serem seguidos.

Paris deveria transformar-se em um grande símbolo napoleônico a céu aberto, ao reunir em sua malha urbana uma série de edifícios e monumentos que celebravam o poder ou as vitoriosas campanhas de Napoleão. Ela deveria ser bordada com locais cujos significados pactuassem com seus interesses e se cercassem de sua retórica. A cidade sofreria, mais uma vez, uma profunda reestruturação simbólica. Esta reestruturação passava por seu foro mais íntimo, com a restauração e remobiliamento das antigas residências reais personalizadas a mando de Napoleão por meio da reativação das antigas e famosas manufaturas reais, como os Gobelins e Sèvres. Mas também extravasava estes espaços mais circunscritos, ocupando aqueles mais corriqueiros, de sociabilidade, graças à decoração em estilo Império, saltando igualmente aos olhos dos transeuntes nas arcadas ou janelas de casas particulares e atingindo seu ápice nas colunas, arcos e igrejas monumentais, todos calcados no estilo neoclássico.

As preocupações de prestígio e monumentalidade, conjugadas com o embelezamento de Paris, levaram à extensão do cais ao longo do Sena; à construção de pontes; à construção do prédio da Bolsa em 1808 (projetada por Brongniart), a reformas para realçar Nôtre-Dame e o Carrousel. Várias ruas foram abertas, como a "de la Paix", a "de Castiglione" ou a "de Rivoli” (fig. 1). Esta última, tendo sido desenhada 
por Percier e Fontaine face às Tulherias, seria um grande exemplo do emprego do estilo neoclássico na arquitetura: toda debruada de arcadas e casas dispostas uniformemente que espelham, em um certo sentido, o desejo governamental de organização social. Estes são apenas alguns poucos exemplos que não dão conta das numerosas intervenções feitas em Paris.

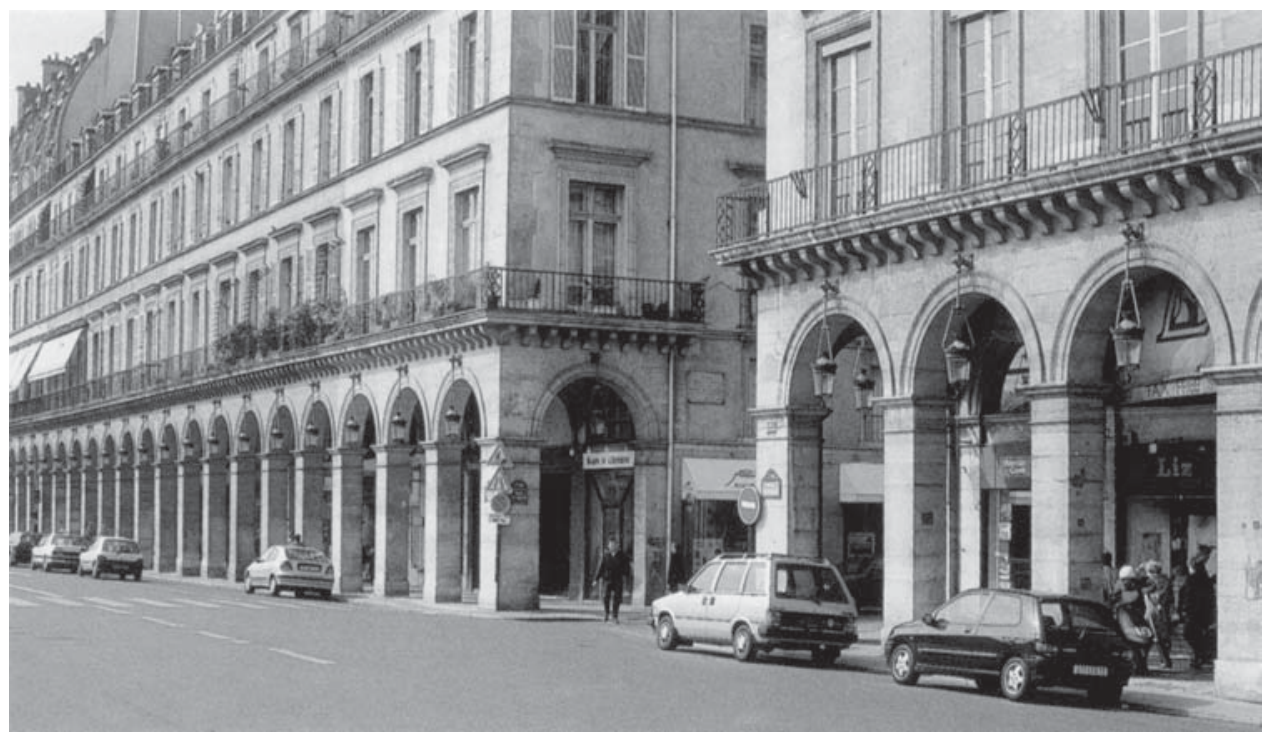

Figura 1: Rua de Rivoli (Paris), Percier e Fontaine (1802-1808)

Alguns pontos mais conhecidos da cidade sofreriam uma inversão de significado com as reformas propostas por Napoleão. Um bom exemplo é o da Igreja de Madeleine (fig. 2), iniciada em 1764. Por um decreto de 2 de dezembro de 1806 (Hautecoeur 1953: 24), data do segundo aniversário de sua coroação e primeiro aniversário da vitoriosa Batalha de Austerlitz, ele decidiria pela reforma da igreja, visando transformá-la em um "Templo da Glória" em honra dos soldados da "Grande Armée”. Para tal fim, foi promovido um concurso cujo primeiro prêmio seria selecionado pela comissão do Institut. Prova de como Napoleão interferia de forma contumaz e direta nos processos de reformas urbanas seria sua arbitrariedade na opção 
pelo projeto de Pierre-Alexandre Vignon, em detrimento do projeto aprovado pelo Institut, que apesar de não ter ganho o concurso seria a seu ver o mais adequado por se harmonizar mais (devido a seu peristilo) com a fachada do Corpo Legislativo e da Bolsa. Os trabalhos de reforma começariam efetivamente em 1807 mas, devido aos revezes sofridos por Napoleão, não seriam finalizados sob suas vistas, sendo retomados entre 1828 e 1842, por J. J. Huvé, quando foram definitivamente finalizados.

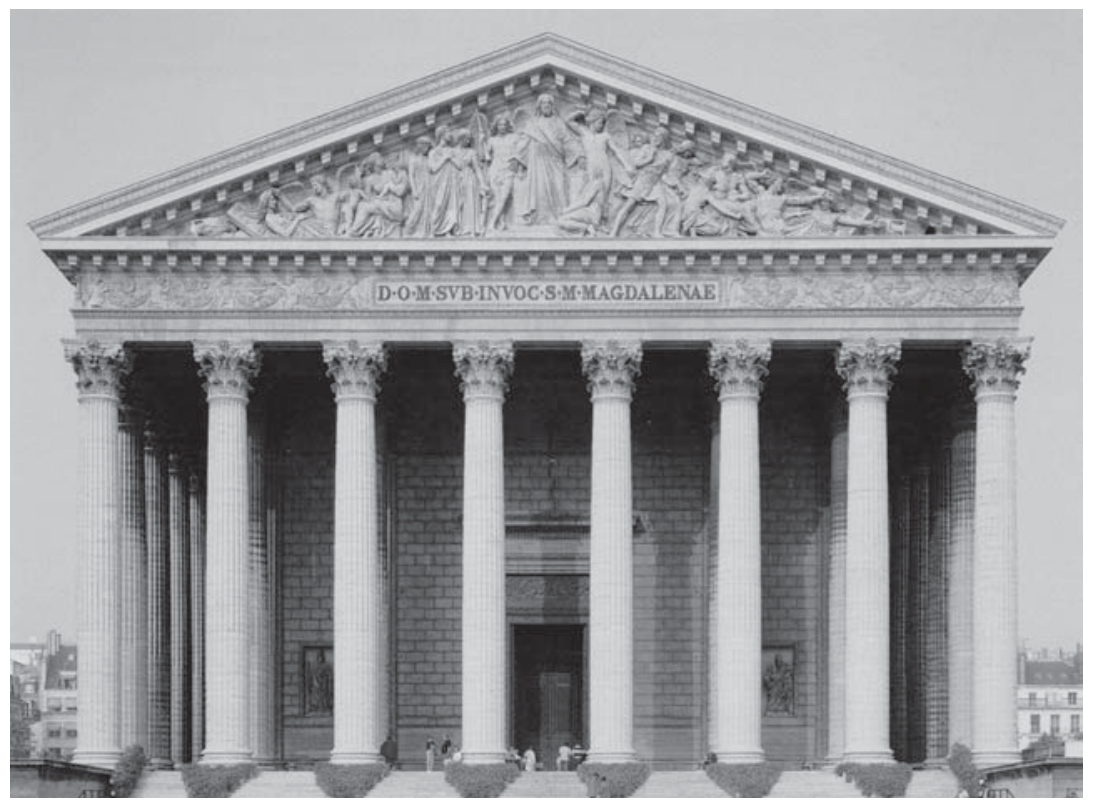

Figura 2: Fachada da Igreja de Madeleine, Vignon (1806)

O Louvre, por sua vez, seria foco de grande interesse por parte de Napoleão. O antigo palácio já abrigava desde 1792 vários quadros, estátuas, bronzes e objetos preciosos que até a queda da Monarquia ornavam outros dois palácios (Versalhes e Tulherias) e que haviam sido depositados em sua grande galeria (Delécluze 1983: 162). Este seria inclusive o propósito inicial das reformas do Louvre a mando de Napoleão: transformá-lo num depósito de luxo para os saques artísticos que vinham na 
cauda de suas conquistas militares . Ele também se constituiria num verdadeiro "Templo da Glória" onde, centralizando e expondo, à vista de todos, os maiores tesouros artísticos, Napoleão demonstrava seu poder de conquista, colocando mais uma vez a arte a serviço de seus fins políticos, além de procurar atrair a cobiça dos grandes talentos da época para concorrer por um lugar em suas galerias com novas obras primas.

Para se ter uma noção aproximada do Louvre antes destas reformas, ficamos com o depoimento de Delécluze, aluno e biógrafo de David, que descreve o antigo prédio por volta de 1796-97, quando sua função primordial era servir de alojamento gratuito cedido pelo governo a vários artistas, suas famílias e seus alunos (um dos ateliês de David encontrava-se justamente aí). Apesar de ser freqüentado por grandes nomes da sociedade e por grandes artistas, apresentava um ar obscuro, quase insalubre:

\begin{abstract}
"Aqueles que hoje [meados do século XIX] percorrem as quatro grandes galerias do velho Louvre, muito duvidam das pavorosas imundícies que elas encerravam ainda por volta de 1796 e 97 (...). Os dois corpos do edifício onde hoje se encontram os museus 'des Souverains' e de 'Chalcographie', ao lado da grande colunata e em volta paralelamente da Rua Rivoli, estavam como as outras partes do Louvre, habitadas por artistas a quem permitiu-se construir interiormente, quando o próprio Estado não os fazia construir, uma seqüência de choças que, tirando toda sua luz do grande pátio, jogavam na obscuridade o resto destas vastas galerias, cujas paredes, assim como as imensas vigas do teto, estavam a nu.

(...)

Estes detalhes bastarão para fazer conhecer qual era o estado interior de um dos mais belos monumentos da Europa, ainda que, para completar o triste quadro, seja indispensável acrescentar que, próximo aos grandes muros negros encostados na colunata, espécies de imensas cubas serviam de latrinas sempre abertas de onde exalava um ar infecto, que apenas se renovava com dificuldade" (Delécluze 1983: 115-6)
\end{abstract}

\footnotetext{
5 "Bonaparte (...) penetrava nas cidades e nas aldeias, requisitava tudo o que era necessário para o exército e apoderava-se daquilo que lhe parecia digno de saque, começando pelos canhões, passando às espingardas e à pólvora e terminando nos quadros dos antigos mestres da Renascença." (Tarle 1973/ 1: 37)
} 
Como bem pretendia Napoleão, o Louvre deveria perder este caráter obscuro e fétido para tornar-se, em breve, o símbolo de seus esforços para elevar a França ao mais alto degrau da civilização, fazendo de Paris o grande centro de referência artística do momento. $\mathrm{O}$ ato de centralizar e monopolizar estes objetos de arte era decididamente um chamariz que voltava todos os olhares para a França tornando o Louvre uma grande vitrine de História e de Cultura e acrescentando nova decoração ao cenário político onde se desenrolava o espetáculo do poder napoleônico ${ }^{6}$. Desta forma, quando Ingres utiliza em seu quadro "Napoleão no Trono Imperial”, terminado em 1806, referências cristãs e clássicas para imprimir uma aura transcendental à representação do imperador, inspirando-se mais especificamente na imagem de Deus Pai que figura no alto do retábulo de Jan van Eyck que seria exibida em Paris de 1799 a 1816 como mais uma das obras apreendidas como butim das guerras napoleônicas, ele não apenas explicitava sua admiração a Van Eyck e seu cuidado em fazer uso de referências à altura de seu modelo, mas colocava em prática uma das ambições de Napoleão: a de confirmar o peso de Paris como capital política e artística do Grande Império (Cf. Boîme 1993: 51).

A posse destes objetos também acabava por criar forçosamente, em um outro nível, um vínculo de subordinação das nações que os perdiam para a França. Ainda que Napoleão tomasse estas apropriações artísticas como legítimas, por serem troféus de guerra, ele tinha todo o cuidado de incluir estas transferências nos tratados de paz para reforçar seu aspecto de legalidade. Colocando-se como aquele que tomava para si o trabalho de "preservar" (ainda que em território francês) a herança cultural destas nações derrotadas, reforçava sua imagem de "salvador" dos territórios oprimidos que agora se encontravam anexados ao Império Francês, criando assim um pretexto prático e moral para o enriquecimento ilícito dos tesouros nacionais da França. Se, por um lado, a exposição, na capital francesa, de objetos de diversas

\footnotetext{
${ }^{6}$ Deixemos claro que algumas das peças trazidas para a França eram também instaladas em museus provinciais, irradiando desta forma uma parcela da civilidade e do orgulho que elas traziam aos franceses para as localidades fora de Paris.
} 
partes do mundo parecia admitir a diversidade de línguas e culturas, sua reunião no Louvre transformava-os em elementos de base do espetáculo da superioridade da França napoleônica, pois só eram admitidos sob a chancela da subordinação à França. A tutela napoleônica destes objetos também parecia querer imputar a estas nações das quais eram apartados uma certa incapacidade de autogestão que Napoleão, paternalmente e com ares messiânicos, se dispunha a suprir.

Como a águia que traz sua presa ao ninho, Napoleão reuniu em torno de si todos aqueles tesouros artísticos para que pudessem alimentar sua glória, engaiolando-os em um de seus palácios. Lembremos que ter seu nome ligado a um artista, tê-lo ao lado e se cercar de suas obras produz uma superioridade no plano da significação que tem implicações no plano político e social: cercando-se de objetos de grande significação e distinção (e aqui podemos considerar os artistas como objetos, tanto quanto suas obras), Napoleão procurava determinar seu "lugar social, sempre relativamente ambíguo, entre as cabeças coroadas da Europa" . Da mesma forma, como em um efeito cascata, a nova nobreza e a família imperial também se cercariam de valiossíssimas coleções de arte e afamados artistas a fim de marcarem seu "lugar social" (Tulard 2001: 139).

Assim, em outubro de 1807, quando do primeiro aniversário da Batalha de Iéna, 50 estátuas, 80 bustos, 193 bronzes e vários quadros de grandes mestres alemães, flamengos, italianos e holandeses, seriam instalados no Louvre com toda a solenidade e pompa (Dayot 1895: 223). Ele passaria a se chamar Musée Napoléon. O orgulho nacional era massageado, mostrando a França como o centro de onde deveria repercutir uma nova ciência e uma nova vida intelectual que se alimentavam de tudo o que podia ser apreendido do estrangeiro e da qual nenhum conhecimento podia escapar.

\footnotetext{
${ }^{7}$ Segundo Pomian (1987: 45), na sociedade há os "homens-coisa" e os "homens-semióforo". Os primeiros formariam a base da sociedade e os outros estariam em seu topo ao representarem o invisível (os deuses ou deus, os ancestrais, a sociedade tomada como um todo, etc.). Para manifestarem seu "lugar social" os "homens-semióforo" devem cercar-se de semióforos, ou seja, de objetos que não têm utilidade prática alguma, apresentando sim grande significação. Assim, quanto mais elevada a posição que se ocupa na sociedade, mais o indivíduo deve se cercar de semióforos.
} 
Assim, com a ajuda de vários arquitetos, artífices e artistas, convocados e patrocinados direta ou indiretamente pelo governo por meio de concursos e pensões, Napoleão personalizaria seus territórios, em especial Paris, traduzindo suas preocupações com prestígio e legitimação. A importância destes trabalhos e sua eficácia seriam fartamente promovidos e celebrados desde ruidosas inaugurações, como a do Louvre, que se encaixavam muitas das vezes em importantes datas do calendário comemorativo napoleônico, até em concursos de redação que lhes emprestavam grandiloqüência, a exemplo dos promovidos por Napoleão no ano XIII (1804) e em 1806, em que o embelezamento de Paris seria o tema das competições (Holtman 1950: 35). Assim, podemos considerar Napoleão como o arregimentador e comandante de dois tipos de exército, aquele formado por soldados e outro formado por artistas, artífices e arquitetos que se dividiam para "batalhar" em diferentes campos, mas tendo objetivos complementares: "with one army he acquired territory and wealth, with other he acquired the means to express them" (Boîme 1993: 14).

A seguir, escolhemos alguns dos monumentos mais famosos da topografia simbólica napoleônica em Paris, procurando entendê-los enquanto suportes de significados e signos de seu poder, centrando-nos mais em seus sentidos políticos do que em seus sentidos estéticos.

\section{Marcos da Topografia Simbólica Napoleônica em Paris}

\subsection{A Coluna Vendôme}

A Coluna Vêndome (fig. 3), também chamada "Colonne de l'Armée" ou "Colonne d'Austerlitz", concebida para homenagear os soldados franceses que honravam os interesses imperiais nos campos de batalha, causou polêmica ao ter a figura da Paz, que deveria ser colocada em seu topo, substituída por uma estátua de Napoleão. Como veremos, tornou-se uma espécie de termômetro político e simbólico, sendo um dos principais alvos da ira política dos anti-bonapartistas após sua queda.

$\mathrm{Na}$ retomada do ritmo de construções que havia sido abalado pelos acontecimentos revolucionários, a Coluna Vendôme encaixa-se, ao que tudo indica, na decisão de Napoleão de executar alguns projetos datados da época da Convenção e do 
Diretório. Em 1800, ainda como Cônsul, ele retomaria a idéia de elevar em cada "chef-lieu" (sede administrativa de departamento) uma coluna "en souvenir des guerriers" (Hautecoeur 1953: 23). Contudo, devido à falta de créditos, apenas em 1806 os desenhos para a coluna parisiense seriam confiados à Jacques Gondoin e Jean-Baptiste Lepère que terminariam os trabalhos de construção em 1810, ano em que também seria inaugurada.

Partiu de Lepère, que havia dirigido uma fábrica de canhões, a proposta de que o monumento contasse com detalhes fundidos e fosse decorada, como a Coluna Trajana de Roma (onde está representada a expedição do imperador romano Trajano contra os Dácios), com baixos relevos, aos quais seriam acrescentadas muitas guirlandas e águias para personalizá-la. Até as proporções da coluna francesa deveriam seguir as da coluna romana. Notemos como a referência estilística à Coluna Trajana traz em si um certo elemento de mimese política entre Napoleão e um imperador romano (em homenagem a quem a coluna romana havia sido construída) e como a opção pela fundição (na qual, como veremos, seriam empregados os canhões inimigos) encharcam de simbolismo político sua estrutura bordada de baixos relevos, dignificando-a como pedestal que elevará a imagem de Napoleão às alturas, bem no centro de Paris, dotando-o assim de uma certa onipresença.

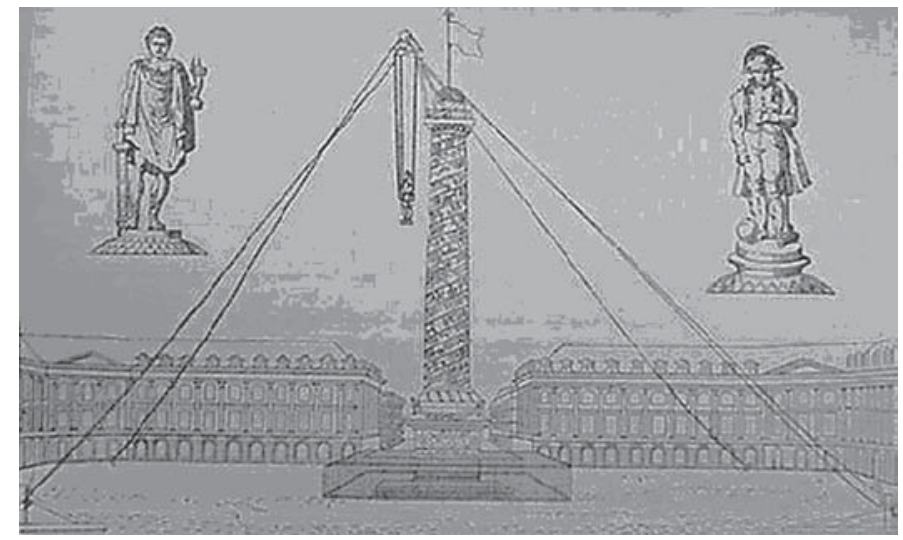

Figura 3: Estátuas da Coluna Vendôme por Chaudet (esq.) e Seurre (dir.) (Paris, abril de 1814). 
Seus detalhes técnicos demonstram por si só sua monumentalidade: revestida com 425 placas de bronze (onde seriam representadas 80 composições esculturais), a coluna, tendo a estátua em seu topo e todos os demais ornamentos, pesaria em torno de $180.000 \mathrm{~kg}$. Estas 80 composições esculturais deveriam evocar, numa literal ascensão gloriosa, envolvendo em espiral o corpo da coluna, as marchas triunfais e os combates vitoriosos do exército francês (seguindo o mote inicial de homenagem do monumento), contando visualmente, quase que dia-a-dia, os feitos da Campanha de 1805, desde o Campo de Boulogne até a Paz de Presburgo. Grande parte do simbolismo da coluna ficaria a cargo do material utilizado para sua construção: mil e duzentos canhões tomados dos exércitos russo e austríaco na Batalha de Austerlitz (1805), uma das mais expressivas vitórias dos exércitos napoleônicos, cuja data (2 de dezembro) sobrepunha a alegria da conquista à comemoração do primeiro aniversário da coroação de Napoleão em Nôtre-Dame.

Retomando os detalhes da coluna, como foi dito inicialmente, a estátua da Paz que deveria coroar seu topo, acabou por ceder lugar à uma estátua em bronze de Napoleão. Da mesma forma como os painéis ali esculpidos levavam, em sua ascensão ao redor do monumento, ao imperador, formando um pedestal que o elevava em meio a Paris, a glória dos exércitos imperiais deveria servir apenas a seu engrandecimento. A estátua em trajes de imperador romano (fig. 3), coroado com louros, tendo em uma das mãos uma espada e na outra um globo (emblema da monarquia universal) encimado por uma figura feminina alada (a Vitória), parece "lembrarnos até que ponto Napoleão prosseguia o sonho insensato de manter nas mãos a Europa e, se possível, também a Ásia, e retê-las com a mesma firmeza com que, no seu monumento, detém a simbólica esfera” (Tarle 1973: II,191). A posição, em pé, guarda uma significação de superioridade que "reside no fato de ele estar livre e não apoiar-se em coisa alguma. Seja porque interfira aí a lembrança da primeira vez em que ele, quando criança, pôs-se de pé sozinho, seja em função de uma idéia de superioridade perante os animais, dos quais quase nenhum é capaz de, livre e naturalmente, erguer-se sobre duas patas - o fato é que o homem em pé sente-se independente [grifo do autor]" (Canetti 1995: 388). Esta criticada substituição foi 
fruto de acaloradas discussões em que o escultor Chaudet (1753-1810), que seria o autor da estátua, finalmente convenceu o então relutante Napoleão que esta seria a melhor maneira de ser representado, dada a forte inspiração calcada na coluna romana (Boîme 1993: 12). Porém o que ficava, para quem o olhava de baixo da coluna, ao nível dos transeuntes, era que se ali se pretendia homenagear algum exército, seria o exército que só era vitorioso por sua chefia, e que, em última instância, apesar de Napoleão repetidamente afirmar seus sacrifícios em prol dos franceses, a nação francesa só fazia sentido para ele quando se fundia em prol dos seus interesses. A cultuação exagerada ao imperador era tão evidente na representação e no posicionamento da estátua (e nos próprios 80 baixos relevos, onde Napoleão figurava em 19) que Bausset, Prefeito de Palácio durante o Império, em um dos parágrafos de suas memórias em que toca no assunto, busca refrescar a situação citando mais que imediatamente as 65 fontes construídas a mando do imperador em 1805 (Bausset 1827: I, 53).

Mas esta não seria a única modificação no plano original do monumento. Ele também sofreria, ainda em sua concepção, a pressão das circunstâncias políticas. Como era de conhecimento público, antes de eleger uma arquiduquesa austríaca como a futura imperatriz dos franceses, Napoleão demonstraria um breve e sério desejo de casar-se com uma princesa russa. Mas este desejo momentâneo chocouse em cheio com o discurso imagético em construção na Coluna Vendôme, fazendo com que as representações das esmagadoras vitórias sobre os russos ali impressas soassem de forma bastante imprópria. Napoleão então ordenou que as cenas que envolvessem os russos fossem excluídas, mas recuou diante do vigoroso protesto de seus oficiais que viam nesta mudança uma afronta à honra conquistada no campo de batalha (Boîme 1993: 12).

Napoleão, exposto ao ar livre numa praça pública, no topo da Coluna Vendôme, reafirmava seu poder e seu desejo de interferência e de presença constante na cidade. Utilizando um dos meios mais marcantes, mas também um dos mais vulneráveis de auto-representação, ele continuava um trajeto iniciado há séculos em que a exposição pública de emblemas e representações do monarca, em especial a representação em pé e a estátua eqüestre, só se afirmara fora das igrejas e dos pátios dos castelos 
pelas garantias de um poder absolutista ${ }^{8}$. Contudo, colocar-se nas alturas mais do que afirmação de um domínio poderia significar igualmente o reconhecimento de uma fragilidade e da necessidade de um meio de proteção que, como veremos, não será suficiente.

\subsection{Arcos do Triunfo}

Os arcos do triunfo, muito difundidos desde a Renascença nas Entradas reais, apresentavam-se como suportes, em sua maioria efêmeros (visto seu caráter quase sempre provisório, dado pelos próprios materiais com que eram montados), para os signos do poder ${ }^{9}$. Recorrentes na montagem de uma cenografia política desde a Roma Antiga, em que demarcavam a entrada oficial de generais ou imperadores depois de uma batalha, purificando aquele que dela retornava e o remetendo para uma esfera mais sacralizada (Souza 1997: II,318), modificavam (momentaneamente ou definitivamente) a cidade que se esforçava por homenagear a ilustre presença. Antes de serem reapropriados pelo Império Napoleônico, já haviam sido tomados

\footnotetext{
${ }^{8}$ Sobre a relação entre exposição pública das representações dos monarcas e o aumento de poder (cf. Warnke 1989: 243-4). Por este ponto de vista, é bastante sintomática a "campanha das estátuas" (representações eqüestres e em pé) de Luís XIV promovida por Louvois, que sucedeu a Colbert como seu ministro (Burke 1994: 108).

9 “Estreitamente associada à instauração do poder monárquico na França, ela [a Entrada] tornou-se mais complexa à medida que a realeza conseguia impor sua ordem. Em fins do século XIII, período em que a vida urbana é ainda pouco desenvolvida, é uma simples cerimônia de acolhimento. Quando o rei chega a uma de suas caras cidades, exerce ali o seu direito de pousada. Os burgueses lhe fornecem cama, comida, abrigo para os cavalos, em troca da promessa do soberano de garantir os privilégios. O desenvolvimento da burguesia urbana transforma o cerimonial. A entrada torna-se um pacto entre a monarquia e a burguesia, que crescem paralelamente, em detrimento dos senhores feudais e do campesinato. A partir do século XIV a acolhida encarrega-se de um ritual mais elaborado: o rei é recebido fora dos muros da cidade, a exibição é ruidosa, animada. A entrada torna-se o equivalente político da Festa do Corpo de Deus: o monarca desloca-se sob um pálio; oferecem-lhe uma sobrepeliz no adro da igreja onde será nomeado cônego de honra. Trata-se, como escreve Bernard Guénée, de uma verdadeira Festa do Corpo do Rei" (Apostolidès 1993: 17-18). Cf. como a Entrada de D. Pedro em S. João del Rei, em 1822, busca a mediação com a entrada de Jesus em Jerusalém (Souza 1997/ 2: 320 e 334).
} 
de empréstimo pela Revolução Francesa, como por ocasião de uma das Festas da Federação, quando se ergueu um exemplar em pleno Champ-de-Mars, em Paris (Hautecoeur 1953: 23).

Possivelmente, o uso destes arcos na cenografia do poder napoleônico (de modo provisório ou não) trazia consigo fortes referências que auxiliavam Napoleão a alinhar-se à uma antiga tradição monárquica. O simbolismo dos arcos do triunfo extrapolava os signos ali impressos e aquele a quem homenageava no momento. Deles ecoavam outras épocas, pois reavivavam na memória grandes Entradas reais como as de Luís XIV, que emprestavam uma dignidade complementar àquele que no presente suscitava suas homenagens pelo simples fato dele ocupar o lugar que pertencera a figuras tão marcantes do passado monárquico francês. As Entradas também possuíam um princípio didático de organização, pois eram momentos em que, por meio de cortejos que espelhavam a hierarquia dos presentes (ocupando o rei o lugar central), a cidade encenava sua correta ordenação social.

Porém, um forte apelo não seria descartado por Napoleão: o de atualizar as entradas dos grandes generais romanos que traziam seus butins de guerra e prisioneiros. Desta forma, Paris vestia-se momentaneamente de Roma, Napoleão de César. Além do mais, a referência mais primária à origem dos arcos do triunfo (o antigo Império Romano) encaixava-os perfeitamente como suporte do estilo neoclássico então em voga: "Napoleão admirava o motivo do arco de triunfo romano, e durante seu regime o Arco do Carrossel (...) e especialmente o colossal Arco do Triunfo da Estrela serviram como lembretes de que o Neoclassicismo havia se divorciado da República e casado com o Império" (Boîme 1993: 13). Assim, além do fator de admiração, por suas formas e pela competição/identificação temporal, os arcos também exteriorizavam uma faceta do uso político das artes, acentuando a relação entre Neoclassicismo e Império Napoleônico.

Dentro dos usos cenográficos dos arcos, apossados pelo cerimonial napoleônico, eles apareciam tanto em sua forma provisória (sendo construídos, muitas vezes, a toque de caixa para alguma comemoração), quanto marcando a cidade de forma permanente em pedra, mármore ou bronze, constituindo-se em marcos simbólicos 
da topografia parisiense, como veremos a seguir. Conjugados às Entradas que ocorriam por ocasião de visitas solenes do soberano à alguma localidade, ao retorno de uma campanha militar bem sucedida ou à chegada de alguma figura importante, os arcos acentuavam o aspecto triunfal destas cerimônias de acolhimento. Voltando da Segunda Campanha da Itália em 1800, de Milão a Paris, as pequenas cidades ergueriam arcos do triunfo para a passagem do vencedor de Marengo e suas tropas (Dayot 1895: 90). Em 1809, algumas semanas após a derrota dos austríacos em Wagram e a imposição da paz à Áustria, o vitorioso exército francês adentrava Paris passando por uma espécie de abóbada formada por vários arcos do triunfo. A grande pompa que tanto honrava as tropas que retornavam e aquele que as comandava entorpecera a multidão ao ponto de talvez nem se notar a baixa de um quarto de seu efetivo (idem: 252). Em 1810, quando da primeira viagem oficial de Maria Luísa, segunda esposa de Napoleão, feita aos departamentos do Norte, "as províncias saudavam com aclamação sua jovem e bela soberana. Em meio a todas estas brilhantes homenagens, observa-se a de um pequeno vilarejo, cujo arco do triunfo foi digno de nota por uma inscrição das mais simples; sobre o friso dianteiro lia-se escrito: PATER NOSTER, e sobre o reverso: AVE MARIA, GRATIA PLENA [referências sacralizantes a Napoleão e à nova imperatriz]" (Bausset 1827: II, 21). Hautecoeur sublinha também que logo após a Batalha de Austerlitz, que se dera em dezembro de 1805, Napoleão, retomando o uso das Entradas reais, teria passado por arcos do triunfo em Estrasburgo e La Villette; ordenando alguns meses depois a construção de dois arcos monumentais e permanentes em Paris (Hautecoeur 1953: 23).

Tratava-se do Arc de Triomphe du Carrousel (Arco do Trunfo do Carrossel) [1806-1808] (fig. 4), silencioso discurso arquitetônico de homenagem aos soldados do Exército Imperial, uma espécie de memorial para Austerlitz (também reforçado pela Coluna Vendôme), e do colossal Arc de Triomphe de l'Étoile (Arco do Triunfo da Estrela) [1806-1836] (fig. 5) que até hoje é observador privilegiado das comemorações oficiais do 14 de Julho, festa nacional dos franceses, dando prosseguimento ao espírito com que fora pensado, o de ser um altar da Pátria, onde os grandiosos feitos revolucionários e imperiais seriam coroados. 


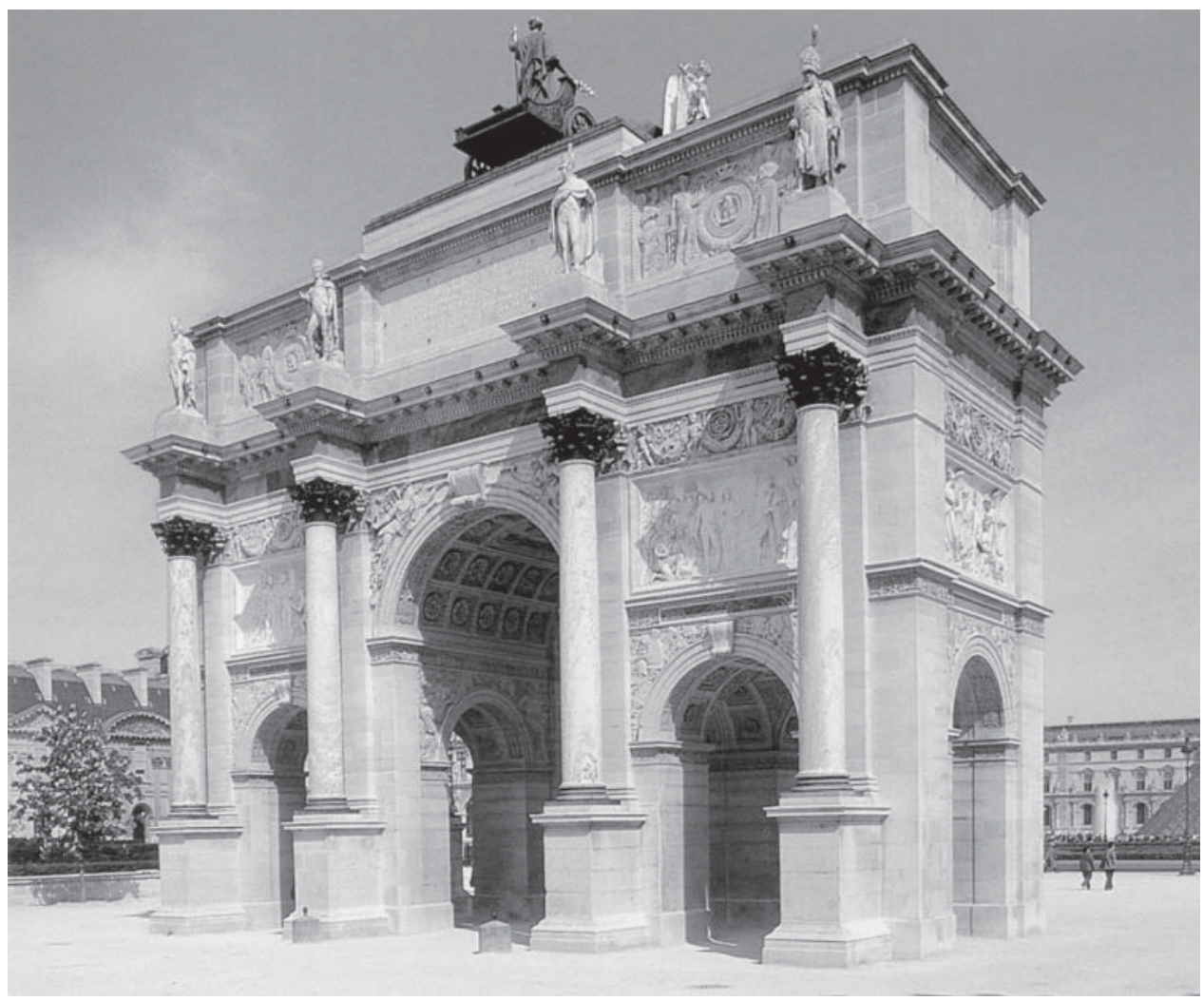

Figura 4: Arco do Triunfo do Carrossel (Paris), Percier e Fontaine (1806-1808)

O primeiro, cuja execução seria coordenada por Denon, espécie de "Ministro das Artes" de Napoleão, foi projetado pela dupla Percier (conhecido por seu compêndio do estilo decorativo do Primeiro Império) e Fontaine (futuro "Primeiro Arquiteto" do imperador). Tratava-se de mais uma parceria bem sucedida que já havia dado certo nos trabalhos de reforma do Louvre e da Malmaison (que havia sido comprada pelo então general Bonaparte e que, depois do divórcio, seria a morada de Josefina). 


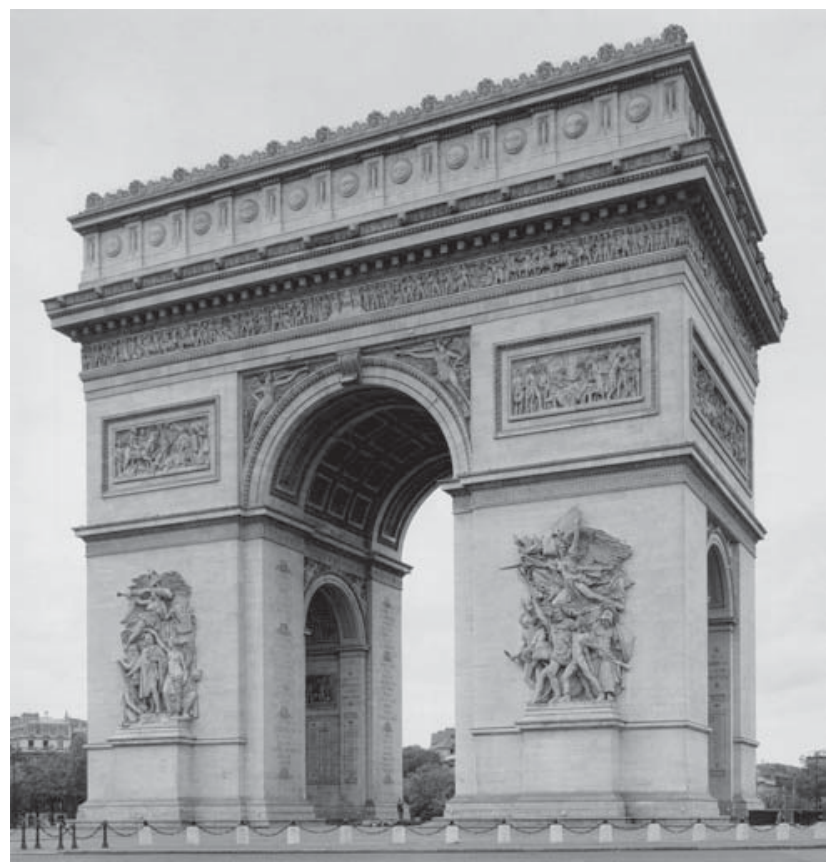

Figura 5: Arco do Triunfo da Estrela (Paris), por Chalgrin (1806-1836)

O Arco do Triunfo do Carrossel deveria servir de entrada ao Palácio das Tulherias, ao que foi desenhado seguindo sua escala. O palácio havia sido adotado desde 1800 pelo então Primeiro Cônsul como sua residência oficial parisiense e esta escolha, ainda que pudesse ser explicada pelo fato de que outros palácios já estavam ocupados pelas assembléias, possuía um valor simbólico todo especial, pois fora a última residência real, tendo sido invadida pelo povo parisiense em 10 de agosto de $1792^{10}$. Para tanto mereceu reformas arquitetônicas e decorativas que envolveram

\footnotetext{
${ }^{10}$ O governo consular se instalou com muita pompa, em 19 de fevereiro de 1800, no Palácio das Tulherias que passou desde então a abrigar a residência de Bonaparte, a sede do governo, os ministérios e as direções gerais, ficando conhecido como "palais consulaire". As assembléias, por sua vez, estavam instaladas da seguinte forma: o Corpo Legislativo, no Palais Bourbon; o Senado, no Luxemburgo; e o Tribunato, no Palais Royal.
} 
Percier e Fontaine, além do arquiteto Leconte, deixando-a à altura de ser considerada o coração político da França napoleônica. Portanto, a localização deste arco, escolhida pessoalmente pelo imperador (assim como seria também o lugar do Arco da Estrela), guardava um sentido de competição, reforçando simbolicamente o lugar de onde emanavam as grandes decisões. O nome do Arco advinha da Place $d u$ Carrousel, onde seria construído, e que possuía esta denominação devido ao famoso carrossel - espetáculo em que rei e nobres faziam manobras a cavalo - aí ocorrido em 1662 a mando de Luís XIV ${ }^{11}$. Durante a Revolução a guilhotina aí seria instalada de 22 de agosto de 1792 a 10 de maio de 1793, salvo no fatídico 21 de janeiro de 1793, dia da execução de Luís XVI que teve lugar na Place de la Concorde. Portanto, tratavase de um palco de grandes acontecimentos e lembranças, cercado de velhos fantasmas que deveriam ser espantados para só restar ali um único drama, um único ator.

Assim, a escolha da localização de um monumento não deixa de ser um discurso de poder, uma forma de se sobrepor ao passado, onde a grandiosidade e a riqueza do monumento que ali se constrói demonstra eficácia não apenas quando ostenta e intimida, mas quando, com seu peso simbólico, achata embaixo de si os significados anteriores que ali se encontravam plantados. Da mesma forma como a Revolução tentara espantar a ostentação e a magia da grande festividade de Luís XIV, amedrontando com a guilhotina, por algum tempo, os fantasmas dos nobres enfeitados do carrossel, Napoleão quis enterrar sob seu arco uma parte do passado Bourbon (ainda que precise do auxílio de seus elementos de persuasão simbólica, como o próprio arco) e do recente passado revolucionário. Assim, não seria mais a populaça sedenta pelo espetáculo de terror da guilhotina ou as cavalhadas do Antigo Regime, mas, possivelmente, as tropas imperiais que iam para o fronte, passadas em revista pelo imperador, quem deveriam restar futuramente a assombrar a praça.

\footnotetext{
${ }^{11}$ Sobre a função social, política e simbólica do espetáculo do carrossel na época de Luís XIV, cf. Apostolidès (1993: 149-50).
} 
Interessante também notarmos alguns cruzamentos entre o Arco do Carrossel e a Coluna Vendôme, que vão desde o ano em que começaram a ser construídos, 1806, passando pelo fato de ambos celebrarem Austerlitz, e continuando com o fato de que o Arco também seria projetado tendo como inspiração um monumento datado da Roma Antiga, no caso o Arco de Séptimo-Severo, do qual é uma cópia reduzida. Contudo, o arco parece ter um sentido simbólico mais horizontal, ao fazer a ponte entre a Roma Antiga e a França do século XIX (atravessando também todos os seus usos a partir da Renascença), enquanto a coluna apresenta um apelo mais vertical, de mediadora entre terra e céu. E assim, como lugares significativos para o poder, eles criam uma espécie de coordenada histórica que promove uma exata localização para Napoleão e seus feitos.

Apesar de seus 14,63 metros de altura total, 17,88 metros de largura e 6,45 metros de espessura, ele ainda seria pequeno perto das medidas monumentais do Arco da Estrela, como veremos. Contudo, sua beleza arquitetônica era reforçada por materiais que emprestavam nobreza, ostentação e a promessa de atravessarem séculos: mármore vermelho para as oito finas colunas coríntias; bronze para suas bases e capitéis; mármore branco da Itália para os frisos e baixos relevos.

É interessante acompanharmos, através do título, os 6 baixos relevos do Arco do Carrossel: la Bataille d'Austerlitz (face leste), la Capitulation d'Ulm (face leste), l'Entrevue de Tilsit (face oeste), l'Entrée de L'Armée Française à Munich (face oeste), La Paix de Presbourg (face sul) e l'Entrée à Vienne (face norte); estes dois últimos figurando isoladamente, um em cada fachada lateral do monumento, enquanto os quatro primeiros, figuram nas demais laterais, aos pares. Como podemos perceber, são os principais momentos da Campanha de 1805 (que encontraremos também na decoração da Coluna Vendôme). O Arco é ainda hoje coroado por uma figura feminina, a França, puxada por quatro cavalos num carro de triunfo. Contudo, Dayot lembra que durante o Primeiro Império seriam apenas dois cavalos, na realidade os famosos cavalos de cobre que ornavam originalmente o Arco do Triunfo de Nero em Roma (que atualmente se encontram na fachada de São Marcos em Veneza) e que seriam restituídos em 1815 a esta cidade, depois da queda de Napoleão. Ainda 
segundo Dayot, este grupo teria sido substituído por outro em bronze (datado de 1828), de autoria de François Bosio, representando a figura alegórica da Restauração em pé num carro triunfal, puxado por quatro cavalos cujo vago simbolismo fez com que fosse considerada a imagem da França (Dayot 1895: 212 e 215 [inclusive nota 1]). Aqui, mais uma vez, vemos os trabalhos de substituição simbólica (instituídos pela Restauração) e o de transferência simbólica (quando Napoleão transpõe para "seu arco" os cavalos do arco de Nero) que marcam também a utilidade do monumento como pedestal (assim como a Coluna Vendôme) de signos de poder e de seus troféus de guerra.

Portanto, a princípio, tem-se a impressão de que no Arco do Carrossel as intenções de reforçar, ao menos de forma mais direta, a imagem imperial ficaram de fora (ainda que, durante sua construção tenha se pensado em uma estátua do imperador representado numa quadriga atrelada à cavalos e conduzida por duas Vitórias, para encimá-lo), ao contrário do que se viu no topo da Vendôme. Podia-se pensar ter havido menos manipulação por parte de seus idealizadores, sem corrupção da intenção original de homenagear Austerlitz e os exércitos franceses que lá lutaram. Mas esta impressão se desfaz ao se ler as legendas que acompanham, nas quatro fachadas, o itinerário das tropas napoleônicas que as ornam nos seis baixos relevos.

Legenda da fachada oeste, que acompanha os baixos relevos l'Entrevue de Tilsit e l'Entrée de L'Armée Française à Munich: “À la voix du vainqueur d'Austerlitz l'Empire d'Allemagne tombe. La Confédération du Rhin commence, les Royaumes de Bavière et de Wurtemberg sont creés. Venise est reunie à la couronne de Fer. L'Italie se range sous les lois de son liberateur."

Legenda da fachada leste, que acompanha os baixos relevos la Bataille d'Austerlitz e la Capitulation d'Ulm: 'L'Armée Française embarquée à Boulogne menaçait l'Angleterre. Une troisième coalition éclate sur le continent. Les français volent de l'ocean au Danube. La Bavière est delivrée, l'armée autrichienne prisonnière à Ulm. Napoléon entre dans Vienne, il triomphe à Austerlitz. En moins de cent jours la coalition est dissoute." 
Legenda da fachada norte, que acompanha o baixo relevo l'Entrée à Vienne: “Bonneur à la grande Armée victorieuse à Austerlitz en Moravie. Le 2 Décembre 1805 jour anniversaire du couronnement de Napoléon."

Legenda da fachada sul, que acompanha o baixo relevo La Paix de Presbourg: "Maître des États de son ennemi, Napoléon les lui rend. Il signe la paix le 27 Décembre 1805 dans la capitale de la Hongrie occupée par son armée victorieuse."

Por nossos grifos nas legendas, destacamos como o nome do imperador ou alguma referência a ele (como na fachada oeste em que ele é lembrado através do epíteto "vainqueur d'Austerlitz", que o acompanharia daí em diante) está sempre presente, mostrando como a glória da França, graças à glória de seus exércitos, não pode se desvencilhar da sua. Assim, ele pode tranqüilamente colocar-se como aquele que sacrifica seus desejos pessoais, em prol de algo maior, do bem de todos os franceses, tendo como única alegria as vitórias que massacram os inimigos, trazendo engrandecimento ao Império. O exército aparece apenas como coadjuvante, até porque se trata de "son armée victorieuse", reforçando seu controle sobre seus súditos e soldados. Napoleão é o "maître”, o "vainqueur”, o "liberateur”, enquanto seu exército não passa de "vitorioso", devendo se contentar com isso. Há, portanto, o uso de um forte recurso discursivo em que a parte (Napoleão) é tomada pelo todo (o Exército, a França). Assim, por mais que os exércitos façam, é Napoleão quem "assina a paz", "triunfa em Austerlitz", "entra em Viena”. A ação de seus homens também é esvaziada ao se atribuir uma série de ações unicamente ao poder de sua voz (o que parece dotá-lo de algo sobrenatural, segundo a fórmula do Gênese bíblico do "Deus disse e assim se fez"), como na legenda da fachada oeste, na qual, com tal recurso, ele "tomba a Alemanha", inicia a Confederação do Reno e "cria" (palavra que reforça o tom divino, genesíaco, de suas ações) os Reinos de Wurtemberg e da Baviera, reunindo Veneza à Itália.

$\mathrm{Na}$ legenda da fachada sul, ele também grava para a posteridade, como havia feito com o epíteto "vainqueur d'Austerlitz", sua lembrança mais cara: o 2 de dezembro, dia de sua coroação em Nôtre-Dame. Portanto, aqui, ele não apenas reforça esta data como algo que deve ser comemorado e jamais esquecido por seus 
súditos, mas ao frisar o 2 dezembro de 1805 como a "coroação de Napoleão" e não como a vitória da Batalha de Austerlitz, ele impõe, nesta superposição de datas significativas para seu poder, uma certa preferência em como o 2 de dezembro deve ser lembrado. Austerlitz perde, portanto, sua autonomia como data comemorativa, e acaba sendo apenas um evento que, por sua vez, comemora, em uma coincidência sobrenatural, a coroação. E é por isso, não pela vitória em si, que seus soldados devem alegrar-se neste dia. Assim, ele afasta o risco que a comemoração de uma data tão importante para seu poder seja eclipsada por outra, optando por escamotear nesta sobreposição de comemorações a importância de um fato que diz respeito apenas a ele (a coroação) diante de outro que envolve também a glória de seus soldados. Tanto assim que em 1807 Napoleão ordenará que a festa de 2 de dezembro seja comemorada tão somente enquanto aniversário de sua coroação ao invés da vitória de Austerlitz (Holtman 1950: 181).

Portanto, se a interferência no Arco do Carrossel parece ser mais amena do ponto de vista das composições esculturais, o discurso em pedra das legendas, volta a desequilibrá-lo em favor de Napoleão, através de uma sintaxe em que a parte se faz maior que o todo.

O Arco do Triunfo da Estrela completa, juntamente com o do Carrossel, ao qual acabamos de nos referir, e a Coluna Vendôme, o que poderíamos chamar de um tríptico monumental da epopéia napoleônica; três das principais "fantasias arquitetônicas” de Napoleão (Boîme 1993: 12). Além de constituírem-se nos monumentos que mais conseguiram imprimir em Paris sua presença e a lembrança de seus feitos gloriosos, podendo ser considerados umas das três mais importantes balizas simbólicas da política de lugares do Império.

Iniciado também em 1806, o Arco da Estrela seria concluído apenas em 1836, extrapolando inclusive a sobrevida fora da política de quem o idealizara para sua glória. A localização deste monumento também seria minuciosamente planejada pelo imperador. Tratava-se da barreira de Chaillot, que se tornaria a barreira de l'Étoile, na época, o limiar entre Paris e Neuilly. Era necessário que fosse visto, impactando principalmente aquele que por algum motivo adentrava ao "ninho da 
águia", dando-lhe as boas vindas e advertindo-o acerca de sua pequenez diante do poder de Napoleão ${ }^{12}$.

As conhecidas intervenções de Napoleão no projeto inicial do arco, valeram-lhe em 1894, o epíteto de "Napoléon Ier Architecte", que seria o título de um artigo publicado neste mesmo ano no jornal Le Temps, em que o autor cita uma fonte de época:

"Em seu plano [para o Arco da Estrela] (...), que é o plano executado, as colunas são suprimidas, o volume está diminuído de um bom terço, as três arcadas se reduzem a apenas uma, e esta arcada se reduz de 50 pés a 45 somente. Em resumo, é a Napoleão I que nós devemos, não pelo detalhe com toda a certeza, mas pelo aspecto geral, pelas proporções, pelo plano de conjunto, o monumento atual. (...) Napoleão (...) possuía o senso (...) da grandeza, e ao invés de termos um pastiche da antigüidade proposta pelos arquitetos oficiais, devemos a ele o fato de termos um tipo novo, de uma beleza verdadeira e de uma originalidade imponente." (Dayot 1895: 207)

Mas ainda que Napoleão tenha interferido nas dimensões do arco, já personalizando-o a partir destas primeiras interferências, ele não anularia com isto suas medidas colossais. Ao ser acabado em 1836, ele teria por volta de 49 metros de altura, quase 45 de largura e cerca de 22 metros de espessura, tendo custado em seu total aproximadamente 9.000.000 de francos (por volta de 6,5 vezes mais que o do Carrossel, que custou 1.400.000 francos, mesmo preço de execução da Coluna Vendôme). Suas fundações em pedra, com 18,5 metros de profundidade, como que expressam a intenção de Napoleão de encontrar-se ali fincado para sempre. A primeira pedra para a construção do monumento seria colocada em 15 de agosto de 1806, dia de São Napoleão, aniversário do imperador. Portanto, ao escolher esta data para o início simbólico da construção do arco, Napoleão encaixava este acontecimento em meio às comemorações que mais do que em qualquer outro dia o honravam,

\footnotetext{
${ }^{12}$ Segundo Chateaubriand, de acordo com uma tradição cara aos bonapartistas, o sol se enquadra exatamente no Arco da Estrela no dia 5 de maio e no dia 15 de agosto, respectivamente aniversário de morte e nascimento de Napoleão (Chateaubriand 1948: II, 677).
} 
reforçando sua identificação com o monumento e emprestando a data de seu nascimento a um outro "nascimento" simbólico, agora em solo francês, com profundas raízes na capital parisiense: o do Arco da Estrela, que lhe prometia longa existência através dos séculos.

Como na Coluna Vendôme e no Arco do Carrossel, o Arco da Estrela também seria decorado com primorosos baixos relevos e frisos sobre os quais os maiores escultores da época exerceriam sua arte por meio do cinzel. Eles representariam a Batalha de Aboukir, a distribuição das bandeiras, a partida dos exércitos, a tomada de Alexandria, a ponte de Arcole, a Batalha de Austerlitz, a batalha de Jemmapes. Em suas paredes figurariam soldados da infantaria, da cavalaria, da artilharia, da marinha e até mesmo uma Marseillaise de cabelos desgrenhados e largas asas que conclama à luta, esculpida por Rudé, além de tantos outros seres, alegóricos ou não. Em meio a todos estes personagens, Napoleão apareceria somente na composição de Cortot denominada “Le Triomphe de Napoléon” (fig. 6). Nesta composição Napoleão é representado tendo em uma das mãos uma espada e estendendo a outra (a mão direita) sobre a cabeça de uma Nação vencida, ajoelhada a seus pés. Ao seu lado, uma Vitória em pé o coroa. Próximo a ela um prisioneiro agachado. Uma figura feminina, que personifica a História, escreve sobre pequenas tábuas as palavras: “Pyramides, Marengo, Austerlitz", nomes de famosas batalhas travadas por Napoleão. Todo o grupo é coroado por uma Fama que, tocando uma trombeta, carrega uma "águia" em um mastro. É o Napoleão salvador e herói, que vem reerguer a França vencida, que é ali representado; aquele que perpetua seu nome e sua lembrança por meio da glória, conquistada com a espada que empunha.

\section{0 Lado Social e Estratégico da Políitica de Lugares Napoleônica}

Além da tentativa de escapar aos assaltos do tempo, a política napoleônica de lugares também deixou transparecer uma preocupação com o controle social, ao procurar satisfazer algumas das necessidades básicas da população: 
"Napoleão estimava que assegurando aos Franceses uma vida mais fácil ele apaziguaria neles o pesar pelas liberdades perdidas. Assim ele prescreveu a Fontaine preparar com Percier 'alguns projetos de casas de educação para as filhas dos militares mortos em serviço, prisões, hospitais, cemitérios nas quatros extremidades de Paris, (...) um palácio das artes, um outro para a Université, casas de retiro para os professores eméritos, arquivos para os títulos do Estado, casernas, estabelecimentos para a administração dos Correios (...), enfim embelezamentos de todos os gêneros para as praças e os passeios da cidade [de Paris]." (Hautecoeur 1953: 26)

Figura 6: "Le Triomphe de Napoléon" (detalhe do Arco do Triunfo da Estrela, Paris), Cortot.

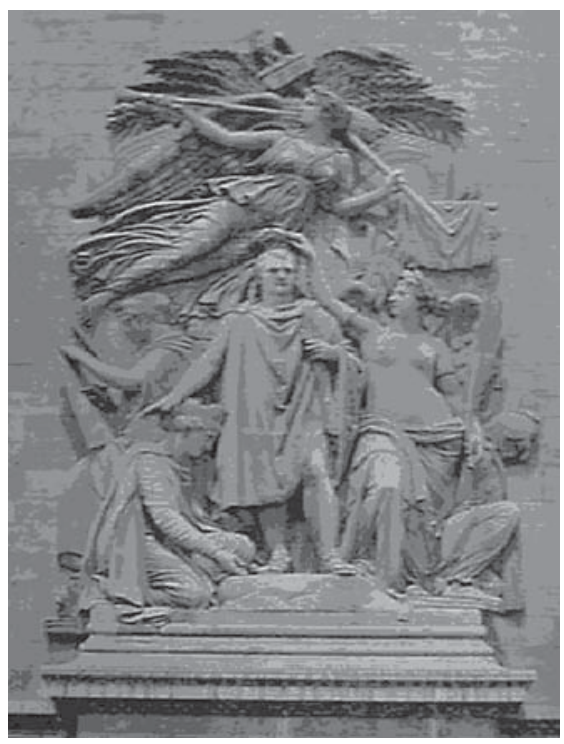

As construções e reformas, por meio dos trabalhos públicos, transformavam-se assim em moeda de troca social: graças aos melhoramentos urbanos procurava-se compensar a menor liberdade imposta pelo regime napoleônico. Temos aí um jogo de compensações psicológicas em que oferecia-se ao súdito-citadino a oportunidade de "sublimar" de alguma forma as amarras do poder e a perda efetiva de liberdade através de um ressarcimento urbano, que se embutia numa espécie de política de deslumbramento: a maior "beleza" da cidade, com seus novos hospitais, cemitérios, escolas, monumentos e jardins, deveria encobrir suas insatisfações. Deste modo, a execução dos grandes trabalhos públicos fazia-se necessária ao interesse popular, mas não deixava de atender à satisfação pessoal de Napoleão, na medida em que criava novos elementos cênicos para a representação de seu poder.

Muitas fontes públicas seriam construídas durante seu governo tanto a fim de amenizar a falta de água em Paris que persistia apesar dos trabalhos já empreendidos 
no século XVIII, quanto auxiliar no combate aos incêndios. Bausset relata que "as 65 fontes que, este mesmo ano [1805] começaram a correr na capital, estimularam o reconhecimento provando que Napoleão sempre se ocupou mais dos monumentos de utilidade pública do que daqueles de uma glória vã” (Bausset 1827: I, 53). Cemitérios, como o Père-Lachaise, projetado por Brongniart, foram construídos fora do perímetro da capital com o intuito de suprimir as pestes ligadas às inumações feitas em cemitérios urbanos ou em terrenos de igrejas. Abatedouros foram erguidos para evitar que os açougueiros, ao abater os animais em seus estabelecimentos, continuassem deixando que o sangue corresse pelas valetas das ruas. Não se podia esquecer de distrair os parisienses e, com o intuito de reforçar esta política de "pão e circo", muitos teatros foram erguidos durante o governo napoleônico. Do mesmo modo, foram construídos mercados cobertos como o de Saint-Germain-des-Prés, de Saint-Martin e do Temple, para citar alguns exemplos em Paris.

Muitas pontes também foram lançadas, como a que ligava a cidade à Ilha de Saint-Louis; a chamada "Pont des Arts" (entre o Louvre e o Institut); a "Pont d'Iena" e a "Pont d'Austerlitz". Se analisarmos mais atentamente, a construção de pontes e ruas guarda fortes simbolismos em uma política de lugares por mostrar como o governo "abre caminhos" por onde desejar, podendo auxiliar (leia-se "interferir") na forma do citadino trafegar pela cidade, "encaminhando-o" de um a outro lugar, chegando ao ponto de, por sua vontade e ato, fazê-lo com seu poder até caminhar "sobre” as águas. Para o caso napoleônico, dar a muitas pontes e ruas o nome de batalhas vitoriosas, ("Iena”, “Austerlitz”, “Castiglione”, “Rivoli”) pode igualmente simbolizar como os feitos vitoriosos são importantes para a estruturação e legitimação do poder de Napoleão que, através deles, continua a avançar, a lançar-se em novos caminhos (ainda que urbanos) em busca da glória.

Além do tom estratégico-social que impregnava muitas obras públicas empreendidas sob seu governo, as reformas feitas nas cidades nunca deixavam de auxiliar o espraiamento dos signos de poder napoleônicos. Estes signos, habitualmente monopolizados pelas grandes colunas, palácios, monumentos e igrejas nos quais eram gravados para emprestar um maior valor simbólico à ostentação, "circulavam” fa- 
cilmente pelas ruas da cidade de modo silencioso e sorrateiro que se opunha à ruidosidade das comemorações oficiais de caráter público (onde estes signos desfilavam), inscrevendo-se nos recantos mais recônditos da cidade, onde discursariam aos mais pobres, devendo apresentar-se portanto, também, em suportes com menos aparato, mas nem por isso menos ostensivos. Como no caso da fonte egípcia da rua de Sèvres [1806-1809] (fig. 7), em Paris, em cujo topo uma imensa águia (símbolo do Império napoleônico), estilizada segundo a arte da terra dos faraós, apresenta suas asas abertas para os transeuntes e os usuários da fonte. Sutilmente, o simples ato de ali se debruçar para se servir de água colocava o citadino sob as "asas" do poder de Napoleão ${ }^{13}$.

Napoleão, portanto, nunca perdeu a oportunidade de imprimir seus signos de poder por onde quer que fosse, marcando ambientes internos e externos com seu símbolo-mor, a águia, seu monograma enfaixado em lauréis, ou mesmo com sua própria imagem. A águia, que serviria como forma de referir-se inclusive a ele, "voaria" por todo o império, pousando nos monumentos, nas fontes, nos móveis que seguiam o estilo Império, em relógios e porcelanas. Ela aparece, inclusive, com ares delicados e românticos, misturada a rosas como no dossel de um dos leitos de Josefina; miniaturizada nos pés do berço do Rei de Roma; chegando a enfeitar o decote do luxuoso traje usado pela primeira imperatriz na Sagração.

\footnotetext{
${ }^{13}$ Ainda sobre esta fonte, podemos estender seu simbolismo, recordando como a lembrança da Campanha do Egito, à qual remete seu estilo, tem um importante papel para a construção da imagem de Napoleão na mentalidade do francês mediano. Ao atualizar seu heroísmo em terras tão misteriosas, enreda-o numa aura quase sagrada, daquele que desafia, em nome da França, à sombra dos grandes faraós, o grande inimigo francês, a Inglaterra.
} 


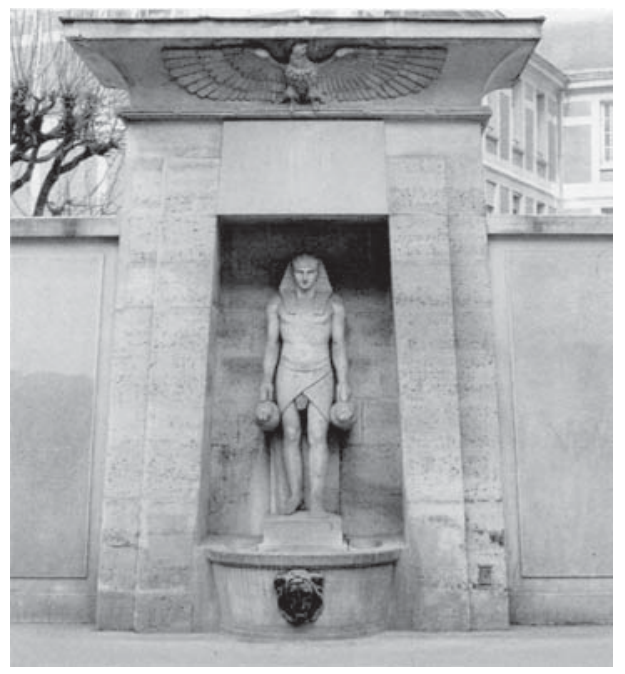

Figura 7: Fontaine du Fellah (rua de Sèvres, Paris), Bralle e Beauvallet (1806-1809)

\section{0s Signos do Poder nos Espaços Privados}

Vimos como Napoleão interferiu na ordenação das cidades, marcando os espaços públicos. Agora vamos sair das ruas e entrar nas casas dos citadinos e nos palácios, percebendo como os signos do poder napoleônico e suas representações conquistaram os ambientes interiores da cidade, imbricando-se de forma bastante natural no cotidiano mais íntimo das pessoas.

A imagem de Napoleão e seus signos de poder passaram a se fazer presentes com cada vez mais liberdade nos ambientes privados ao utilizarem como suporte de circulação uma infinidade de bens de consumo que os tiravam da dependência de suas aparições públicas nos grandes monumentos, nos nomes dos lugares, nas fontes, nos grandes palácios e nas comemorações, que eram deixados porta afora. Estes bens de consumo, fortes complementos para a idéia da presença imaginária do soberano por todos os lugares e para o fortalecimento do sentimento de seu poder, acabavam por naturalizá-lo cada vez mais enquanto autoridade legítima, por insinuar através do cotidiano das pessoas alguma adesão a ele ou algum grau de submissão calada e passiva: "Sur la pomme de leurs cannes, sur le ouvercle de leurs tabatières, sur le fourreau de leurs pipes, sous le chaton mobile de leurs bagues, il y a le profil de Napoléon." ${ }^{14}$

Durante a Restauração, período de duras medidas iconoclastas favorecidas pelos Bourbons e simbolizadas inicialmente, como veremos, pela substituição do César Napoleônico da Coluna Vendôme pela bandeira monárquica, estes objetos ainda

\footnotetext{
${ }^{14}$ Escrito de época, 1815 (de Henry Houssaye) citado por Dayot 1895: 121.
} 
possibilitariam um cripto-culto ao imperador, que só se revelava para aqueles de confiança e que dividiam mais intensamente a intimidade da família ${ }^{15}$. Estes mecanismos de adoração secreta e protesto silencioso mas audacioso, fizeram sua primeira aparição durante o primeiro exílio de Napoleão, na Ilha de Elba, aparecendo como fortes rivais da contrapropaganda bonapartista promovida oficialmente pela Restauração. Estes objetos mantinham um discurso ambíguo que se modificava dependendo de quem os lançava sob as vistas. Ora concordavam com a iconoclastia promovida pelos Bourbons, ora se opunham completamente a ela, num interessante jogo de esconde-esconde, que denunciava algum tipo de simpatia que não necessariamente apresentava uma faceta político-ideológica pelo bonapartismo, mas muitas vezes um compadecimento e piedade pela figura de Santa Helena que se modelava segundo a imaginação popular como um novo Prometeu acorrentado a um rochedo pelos deuses, ou seja, pelos reis que ele desafiara. Havia uma infinidade destes suportes que iam desde objetos de decoração aos de uso doméstico ou pessoal, dominando e sendo dominados pelo imaginário popular, transformando Napoleão e os signos de seu poder em verdadeiros fetiches e modismos, que devem ter sido transportados pelos tempos via testamentos e dotes.

Este culto doméstico do Imperador teria se expandido muito por volta de 1814 (ano da primeira abdicação) indo num crescente até mais ou menos 1830 (Dayot

\footnotetext{
${ }^{15}$ No romance $O$ Vermelho e o Negro, de Stendhal, Julien Sorel, por exemplo, apesar de passar por anti-bonapartista perante a sociedade da pequena cidade de Verrières, mantinha escondido no forro do colchão, numa pequena caixa de papelão preta e lisa, uma gravura de Napoleão que queimaria no primeiro momento em que correra perigo de ser descoberto: “'O retrato de Napoleão', dizia a si mesmo, sacudindo a cabeça, 'encontrado oculto no quarto de um homem que faz praça de tamanho ódio ao usurpador! (...). E, para cúmulo da imprudência, no papelão branco detrás do retrato, linhas escritas por minha mão! E essas não podiam deixar dúvidas sobre minha admiração excessiva! E cada um desses enlevos de amor traz data! Um até de anteontem! Toda a minha reputação por terra, anulada em um momento!', pensava Julien, vendo queimar a caixa.” (Stendhal 1987: 62). Ainda dentro deste cripto-culto, segundo Pigeard, durante a primeira Restauração, os velhos soldados e os bonapartistas se referiam a Napoleão como "l’Autre” e após sua morte, ainda se falará durante muito tempo de "Lui" entre os camponeses. Para outros apelidos dados a Napoleão durante sua carreira (cf. Pigeard 2000: 242-3).
} 
1895: 121). Mesmo na Inglaterra, que finalmente aprisionara Napoleão para todo o sempre e onde mais do que em qualquer outro lugar seu nome e lembrança estariam destinados ao desprezo, Chateaubriand pôde presenciar o contrário, muito provavelmente fruto deste culto. Comenta ele que andando por Londres, no ano de 1822 (portanto, no ano seguinte à morte de Napoleão em Santa Helena), pôde perceber e atestar a abundância de lembranças de Bonaparte que parecia mergulhar a cidade num "enthusiasme bête" pelo recém falecido ". Ele prossegue dizendo que as "mémoires de Bonaparte pullulait; son buste ornait les cheminées; ses gravures brillaient sur toutes les fenêtres des marchands d'images; sa statue colossale, par Canova, décorait l'escalier du duc de Wellington" (Chateeaubriand 1948: III, 105). Ainda que a exposição proposital desta estátua de dois metros e meio de altura e sete toneladas, representando Napoleão nu como Marte, e que figurou no Louvre até abril de 1816 quando foi vendida à Inglaterra por 66.000 francos e cedida a Lord Wellington (Id., Ibid.), talvez fosse mais um troféu de guerra usado para escárnio do que culto ao imperador, vislumbramos como sua imagem vinha sendo veiculada e usada também nos ambientes londrinos.

Muitos destes objetos do cotidiano tinham seu molde original feito por um conhecido artista que se enredara no patrocínio estatal do imperador (e aí se podia encontrar peças inspiradas tanto nos trabalhos monumentais de David quanto nos do miniaturista Isabey), o que garantia o controle e a circulação de uma representação oficial. A produção em larga escala, incrementada pelo incentivo dado por Napoleão ao desenvolvimento técnico-industrial, permitia que grande parte pudesse ser feita num tempo reduzido e com preços mais acessíveis. Muitas, por exemplo, foram as estampas publicadas na época do Império, tanto na França, quanto na Itália, na Alemanha e até mesmo na Inglaterra onde a figura do imperador era representada das

\footnotetext{
${ }^{16}$ Não nos esqueçamos que o tom de crítica presente nas palavras de Chateaubriand revela sua inimizade profunda a Napoleão. Ele, através de seus escritos, foi um dos mais hábeis agentes na construção da Lenda Negra napoleônica.
} 
mais diversas formas, moldando-se muitas vezes ao gosto público pela fantasia. Mas havia os objetos exclusivos, produzidos por encomenda oficial ou de um particular. Muitos eram presenteados a importantes figuras - os chamados presentes diplomáticos - como as tapeçarias Gobelins e as porcelanas de Sèvres, oferecidas, por exemplo, ao Conde Tolstoi, grande-marechal da Rússia, pelo Imperador na entrevista de Erfurt (Bausset 1827: I, 247), em 27 de setembro de 1808, quando de seu encontro com o Czar Alexandre; ou os 11.140 francos em porcelanas dadas ao rei e à rainha de Wurtemberg em 30 de setembro de 1806, dos quais constava um vaso de fundo azul, avaliado na época em 1.500 francos, elaborado por Percier, cujo tema alegórico era o imperador conduzido pela Vitória (Dayot 1895: 228). A coroação também seria uma oportunidade de se distribuir tais presentes aos personagens mais distintos que ali compareceram. Tal era o incentivo e a importância destes tipos de presentes que auxiliavam na exportação de representações de Napoleão e de seu governo que em uma carta enviada ao "Intendant général de la Maison de l'Empereur”, datada de 22 de abril de 1806, Duroc, “Grand Maréchal du Palais”, falava da intenção de Napoleão de substituir os presentes feitos pelas Relações Exteriores em diamantes por presentes feitos nas manufaturas de Sèvres e dos Gobelins, devendo em todos serem colocados retratos de Sua Majestade, vistas de Paris e de diferentes palácios imperiais (Dayot 1895: 230).

A reativação e apropriação da produção das antigas manufaturas reais dos Gobelins (tapeçarias) e de Sèvres (porcelanas) criadas e incentivadas pelos reis franceses com o intuito de também promoverem por meio de suportes decorativos suas imagens e equiparem luxuosamente suas residências, traziam consigo um certo ar de legitimidade e tradição ao processo de fabricação destes objetos, luxuosos ou não, que também iriam servir nas reformas dos palácios que deveriam ser personalizados, ou como presentes diplomáticos ou objetos a serem vendidos ou dados ao grande público. Seriam fábricas de glorificação e de popularização da imagem de Napoleão, a partir das quais, especialmente, ele anunciava sua supremacia política e se colocava como o legítimo herdeiro dos antigos domínios reais. $\mathrm{O}$ incentivo voltado a Sèvres e Gobelins era apenas um exemplo da atenção que vinha sendo dada, 
desde o início do Consulado, à indústria em geral e ao desenvolvimento técnico visando a disputa econômica entre França e Inglaterra.

O luxo que caracterizou o Império, indicativo definitivo da movimentação de Napoleão rumo ao Antigo Regime e seu afastamento da Revolução, aparecia como outro sintoma desta preocupação com o desenvolvimento técnico-industrial da França, achando aí uma justificativa mais racional do que a pura e simples ostentação. Napoleão, fazendo uso de uma política econômica de sedas e veludos, passou a exigir nos trajes de sua corte e dos funcionários do Estado, assim como na decoração de seus palácios, o uso de tecidos e ornamentos luxuosos a fim de favorecer as indústrias que os produziam e desenvolver o comércio interno ${ }^{17}$, favorecendo também as exposições de produtos industriais ${ }^{18}$. Assim, as artes decorativas, através do chamado estilo Império, para além do apelo estético e de status dos novos ricos, generais vencedores e financistas, apresentavam-se em última instância como dispositivos de incentivo econômico e como um discreto suporte para a entrada das mensagens políticas de Napoleão em muitas casas, através de sedas, tapeçarias e móveis. Afinal, a decoração interior calcada no gosto pelo colossal e na imitação dos modelos gregos, egípcios e romanos tão típicos do estilo apenas espelhava em uma reduzida escala a própria ambição de Napoleão, cujo apelo ao colossal e ao heróico já dominava o exterior por meio da arquitetura neoclássica. A riqueza em seus detalhes de ornamentação ganhava brilho com a seda, o veludo, e alguns outros materiais que, não coincidentemente, até então eram destinados aos monumentos, como mármores e bronzes.

Cabe ainda salientar que este estilo inspirado na Antigüidade, extremamente luxuoso, também se reconhecia nas ruas, através da moda que levava igualmente o

\footnotetext{
${ }^{17}$ Como salienta Bausset, o exemplo começava pelo próprio Imperador: "ses vêtements ordinaires n'avaient rien de remarquable. Un jour, voulant donner l'exemple d'un encouragement utile aux manufactures de Lyon, [itálicos nossos] il parut à l'un des cercles de l'impératrice Marie-Louise en habit de velours de couleur foncée avec de boutons en diamants... Il n'était plus le même et me parut fort gêné dans ce costume, nouveau pour lui." (Bausset 1827: II, 191)

${ }^{18}$ Um famoso exemplo do costume que havia sido inaugurado durante o Consulado, foi a Exposição industrial de 1806 que teve lugar na exposição nacional, que celebrava as vitórias francesas em Austerlitz, ocorrida na Esplanade des Invalides, que contou com cerca de 1500 expositores (Boîme 1993: 21).
} 
epíteto de estilo Império, na qual os caros tecidos (que eram os mesmo usados nos estofamentos e paredes das casas luxuosas), as jóias, os penteados, os camafeus eram, além de pastiches da Antigüidade e de símbolos do esforço de uma França industriosa, uma codificação social burguesa.

Um dos inúmeros exemplos de como a decoração e o uso das antigas manufaturas reais colaboravam com a glória napoleônica está na chamada "Mesa dos Palácios Imperiais", onde numa base circular, feita com porcelana de Sèvres e bronze, seriam representadas as várias residências imperiais em nove medalhões, tendo no medalhão central a vista das Tulherias, numa cena maior que as demais e mais proeminente, afirmandoa como o centro simbólico da França. Ainda deveriam ser incluídas aí, vistas de propriedades estrangeiras das quais Napoleão havia se apropriado da nobreza local. Apesar da pintura decorativa do topo da mesa nunca ter sido concluída, o projeto em si já demonstra o alcance do poder do Imperador, que é resumido e simbolizado pelas residências ali representadas.

\section{Paris: uma Cidade Napoleônica?}

"Uma profunda desconfiança impediu-o de admirar Paris (...); só os monumentos deixados por seu herói o tocavam.”.

(Stendhal, 1987: 235)

Poderíamos neste ponto dar por encerradas nossas análises, não fossem os interessantes trabalhos ora de desconstrução, ora de reconstrução que ainda continuariam ao longo do século XIX acerca da imagem de Napoleão e de seus símbolos na cidade de Paris. A começar pela febre iconoclasta que seria oficialmente levada a termo a mando de Luís XVIII. Aliás, um dos mais simbólicos destes fenômenos iconoclastas teria lugar quando da primeira invasão de Paris pelos aliados. Seu alvo seria a Coluna Vendôme, cujo forte discurso visual que aí se enrolava e explodia em seu topo através da figura cesárea do imperador, fazia dela o baluarte por excelência do poder napoleônico.

Até aquele momento, a presença da figura de Napoleão no alto da coluna trazialhe, sob algum aspecto, um sentimento de proteção e intangibilidade, ao mesmo tempo em que expressava a extensão do raio de alcance que ele possuía por Paris, pela França, 
pela Europa inteira. Mas esta intangibilidade simbólica seria abalada muito antes de Marx pronunciar, em tom de vaticínio, a famosa frase, em seu 18 Brumário: "quando o manto imperial cair finalmente sobre os ombros de Luís Bonaparte, a estátua de bronze de Napoleão ruirá do topo da Coluna Vendôme” (Marx 1977: 126). A partir da primeira entrada dos aliados em Paris (30 de março de 1814), o monumento sofreria uma série de furiosas investidas por parte dos anti-bonapartistas, o que se estenderia pelo século XIX afora quando a imagem de Napoleão seria "precipitée du haut de son piédestal par le souffle des révolutions" (Dayot 1895: 154).

No dia seguinte ao fatídico 30 de março de 1815 no qual, segundo Dayot, que reproduz a situação a partir do texto de um historiador da época, a coluna sofreria o primeiro ataque, os realistas não tardariam a voltar, nesta ocasião, sua ira (ao que consta, sem a intervenção dos estrangeiros que ocupavam Paris) contra o famoso baluarte napoleônico fincado no meio de Paris (Dayot 1895: 154-155). Teriam inicialmente tentado derrubar a estátua a marteladas e até com o auxílio de cabos atrelados a cavalos, o que foi em vão. Depois de pensarem em dinamitá-la, teriam decidido serrar-lhe os tornozelos, conseguindo, finalmente, removê-la. Alguns dias (mais precisamente em 8 de abril de 1814, por volta das 6 horas da tarde, uma sextafeira da Paixão) e muitos esforços depois (já sob as ordens do governo provisório, que canalizava em seu proveito a ira espontânea da populaça que se iniciara dias antes) o colossal Napoleão de Chaudet (fig. 3) seria finalmente destituído de seu trono de bronze, como seu equivalente em carne e osso que se vira compelido a abdicar, constituindo-se num dos grandes exemplos do expurgo que os símbolos napoleônicos sofreriam com o retorno dos Bourbons. Em seus lugares entrariam, respectivamente, a bandeira realista e Luís XVIII que sairiam de cena rapidamente durante os "Cem Dias", retornando com a ida do imperador para Santa Helena. Logo depois, quando houve necessidade de bronze para uma estátua de Henrique IV (concebida por Lemot) que seria erguida no Pont-Neuf, não se hesitaria em fundir a estátua de Chaudet para este fim. Aqui, se por um lado a necessidade de se exaltar um dos grandes monarcas franceses levava à canibalização de Napoleão, como se através desta aglutinação ele pudesse ser eliminado da história francesa e se tomasse 
de volta tudo aquilo que ele usurpara da tradição monárquica em seu proveito, por outro lado Napoleão simbolicamente, sem maiores esforços, finalmente se amalgamava, ainda que através do nobre metal, ao passado monárquico francês.

Em 1832, contudo, ele voltaria a ocupar o topo da Vendôme, que perderia assim a "provisória" bandeira branca dos realistas, mas não em sua fantasia de César. Tratava-se de uma nova estátua, encomendada a Charles Seurre (fig. 3) que concorrera com vários outros escultores. Nela o ex-imperador seria representado de uma forma bastante semelhante à imagem canônica com que estamos acostumados: em pé, com o tradicional e sóbrio costume de "petit caporal”, seu longo casaco cinza, seu pequeno e característico chapéu e na pose que o consagraria com a mão posta no colete: "L'image ainsi interpretée du vainqueur d'Austerlitz ne tarda pas à devenir très populaire malgrè l'aspect peu décoratif de sa silhouette”" (Dayot 1895: 155). Assim, esta estátua concorreria para cristalizar para a posteridade um tipo de representação, sendo possivelmente a chave para se entender porque múltiplos Napoleões (frutos de vários esforços políticos e artísticos coordenados) acabariam por ceder lugar a um único Napoleão que descartava toda uma riqueza iconográfica ${ }^{19}$.

Talvez se tratasse de uma cartada do próprio rei francês da época, Luís Felipe, que se apoderava da imagem de Napoleão, destituindo-o de suas extravagantes características imperiais (cesáreas) ao impor uma imagem escolhida através de um concurso (o que dava a impressão de algo democraticamente escolhido) que impunha uma espécie de "retrocesso" na imagem imperial, ao apresentá-lo com o despojado aspecto de cabo do exército, fazendo esquecer as insígnias e o pomposo manto. Devemos lembrar que fazia parte dos projetos de legitimação de Luís Filipe a conciliação entre os ideais da monarquia tradicional e as idéias liberais desencadeadas com a Revolução Francesa, assim como a canalização do culto a Napoleão, sem no entanto endossar a causa bonapartista, a fim de converter seus simpatizantes em Orleanistas (Marrinam 1988: 146). De onde percebemos como um projeto de legitimação acaba

\footnotetext{
${ }^{19}$ Em nossa opinião a estátua de Seurre pode ser tomada como a grande matriz para a popularização da pose que passaria para a história como sua marca registrada. Lilia Schwarcz mostra a extensão de
} 
sendo curiosamente fagocitado e digerido por outro. Tanto assim, que o próprio Luís Filipe viria inaugurar a nova estátua solenemente em 28 de julho de 1833, durante as festas destinadas a celebrar o terceiro aniversário da Revolução de 1830... Portanto, não se trata realmente de acatar a figura de Napoleão e restitui-la ao seu lugar de destaque, mas sim domá-la em seu favor, esvaziando-a de seus aspectos enaltecedores iniciais.

Assim, desde a primeira queda da coluna Vendôme, Napoleão só voltaria a readquirir o aspecto sagrado e imperial, pelo qual tanto se esforçou, sob Napoleão III. Seu sobrinho faria substituir o pouco pomposo "pequeno Cabo" novamente pelo César, a fim de recuperar a idéia dinástica que ali se encontrava insuficientemente simbolizada. O general-imperador ganhava novamente o direito de figurar no topo da Vendôme, a partir de 1863, através de uma terceira representação, a de Dumont. Numa espécie de pastiche da obra de Chaudet, o velho e longo casaco seria despido para trazer de volta os trajes romanos e o pequeno chapéu daria lugar aos louros. Porém, durante a Comuna de Paris, a estátua sofreria outra queda, desta vez por ordem do governo insurrecional. Em 16 de maio de 1871 os gritos de "Vive le Roi! Vive Louis XVIII!", ouvidos em 1814, dariam lugar aos de "Vive la République! Vive la Commune!". Contudo, em 1875, o monumento seria restaurado segundo seus detalhes originais, graças a novas modelagens feitas de acordo com os moldes primitivos que haviam sido conservados. Prosseguindo com a trajetória polêmica do monumento, colocou-se a questão de substituir a figura de Napoleão pela da França e, ainda que esta resolução tenha sido admitida através de um decreto, não tardou a dar licença para que a estátua de Dumont voltasse a seu antigo pedestal.

Como podemos perceber, as investidas à coluna foram dirigidas mais à estátua do que à coluna em si, lembrando uma espécie de malhação do Judas ou mesmo de

sua difusão no século XIX, ao ser curiosamente adotada e interpretada, inclusive, por nosso imperador d. Pedro II: "No mesmo período em que, como diz Freyre, o imperador troca 'a coroa pela cartola', [a partir de 1860] começa a se tornar comum d. Pedro II aparecer com uma certa postura corporal inédita: trazendo uma das mãos metida dentro da casaca, numa referência à famosa pose consagrada por Napoleão.” (Schwarcz 1998: 333) 
Paixão (se recordarmos que a primeira retirada da estátua aconteceria coincidentemente numa Sexta-Feira Santa). Nestes linchamentos simbólicos os que se opunham a Napoleão, se não podiam ter o prazer de supliciá-lo fisicamente, se contentavam em canalizar seus ódios para sua figura em bronze. Atacando-a, atacavam simbolicamente seu poder, mostravam sua vulnerabilidade e sua ilegitimidade, demonstrando como todos os seus esforços para se fundir em bronze ou se cristalizar no tempo como monarca haviam sido em vão. Eis a forte necessidade psicológica de, através de sua estátua, arrancá-lo de Paris (como havia sido arrancado da Europa através de seu exílio), de humilhar sua suposta majestade ao despi-lo de seus trajes romanos, açoitá-lo e feri-lo com martelos, buscando de alguma forma desenraizá-lo para sempre da História pelo ato de desenraizá-lo de seu pedestal de bronze, desconstruindo-o tanto do ponto de vista de uma mimese política quanto de uma topografia simbólica.

Porém, todos os esforços para exorcizá-lo, empreendidos pelos governos que se seguiram à sua queda, segundo uma psicologia do poder, faziam-no, ao contrário, mais presente, ao ponto de termos um segundo Napoleão no governo. Posto tudo isso, há razão em considerarmos o monumento como um verdadeiro termômetro político do século XIX na França.

Outro interessante ponto da (des)construção simbólica do poder napoleônico que continuaria a polemizar pelo século XIX seria o Arco do Triunfo da Estrela cujos planos de finalização se viram prejudicados com a primeira abdicação, em 1814, e seriam definitivamente abandonados quando do exílio de Santa Helena. Apesar de toda a política iconoclasta dos Bourbons que, a partir da Restauração, procurariam supliciar a lembrança de Napoleão por meio do ataque às suas efígies e cifras (como no exemplo da Coluna Vendôme) chegando ao ponto de mandar arrancar os baixos relevos do Arco do Carrossel (Dayot 1895: 208) ${ }^{20}$, a imensa massa inacabada que constituía então o Arco da Estrela permaneceria como um espectro amorfo da passagem de Napoleão pelo trono francês. O monumento em estado inacabado talvez nem precisasse ser destruído, afinal já simbolizava por si só a frustração e interrupção do megalomaníaco sonho napoleônico de poder e dominação. Além do mais, não tardaria em se ver transformado, pela ação do tempo, em mero escombro, 
perdendo desta maneira seu caráter de perpetuação. Assim, em última instância, o próprio tempo que ele buscava vencer enquanto monumento iria reverter seu inicial simbolismo de glória, transformando-o em um outro monumento, agora não mais napoleônico, mas sim anti-napoleônico. Contudo, ele seria terminado e inaugurado em 29 de julho de 1836 , sob a Monarquia de Julho de Luís Felipe, três anos depois da "reentronização de Napoleão", com a nova estátua de Seurre, no topo da Coluna Vendôme.

Seguindo a mesma tendência do Arco do Carrossel e da Coluna Vendôme, a questão da decoração do topo do monumento atravessaria o século XIX. Durante os festejos de julho de 1838, uma enorme pintura inspirada no projeto de Seurre "ainé, que planejava representar no cimo do arco uma França vitoriosa sobre um carro de seis cavalos parando sua triunfal marcha para receber a Carta Constitucional, serviria de decoração ocasional. Em 1840, quando do retorno das cinzas de Napoleão à França, a pintura seria substituída por uma maquete em que Blouet representaria o imperador em pé, cercado pelos atributos da Vitória. Em fins do século XIX, uma outra maquete ainda tentaria, em vão, coroar, agora pela última vez, o Arco da Estrela. De autoria do escultor Falguière e apresentando uma grande aproximação com o projeto de Seurre “aîné”, a República triunfante (e não mais a França) apresentavase no tradicional carro puxado por cavalos fogosos. Porém, "après avoir figuré sur le sommet de l'Arc, à l'état de maquette en carton, pendant plusieurs mois, le quadrige orageux de Falguière disparut à son tour, ayant subi les critiques les plus cinglantes et les coups de vent les plus violents" (Dayot 1895: 210) ${ }^{21}$.

Dava-se ao topo do monumento um aspecto de palco teatral de onde, encerrada uma dada temporada (política), alguns artistas eram banidos, destituídos dos papéis principais, e outros eram convidados a preencherem-nos. Deste modo, as discussões em torno da coroação do arco ilustram como a dança de símbolos e de alegorias

\footnotetext{
${ }^{20}$ Que seriam substituídos por temas tirados da guerra da Espanha, em que, não coincidentemente, Napoleão havia sofrido o primeiro de seus grandes revezes, e que só seriam restituídos sob Luís Filipe.
} 
seguia o ritmo das preocupações políticas vigentes, reforçando a importância do uso de imagens para o poder.

Contudo, o último projeto relacionado à construção simbólica do poder napoleônico teria lugar após sua morte ocorrida em 5 de maio de 1821. Napoleão continuaria a agir, ainda que passivamente, na topografia da cidade de Paris, seguindo sem planejar com suas pretensões temporais de eternização. Não nos referimos ao término do Arco do Triunfo da Estrela sob a Monarquia de Julho ou à restituição de sua estátua à Coluna Vendôme, mas sim ao retorno de suas cinzas que seriam depositadas nos Invalides, a mando também de Luís Filipe que, consciente da tentativa mal sucedida da Restauração de lutar, por meio da proscrição de seus signos, emblemas e representações contra o fantasma mitificado de Napoleão que entrava cada dia mais profundamente no coração da opinião pública, resolvera evocá-lo a seu favor. Encarregando, inclusive, um de seus filhos de ir a Santa Helena para trazer os despojos mortais do imperador, para que fossem triunfalmente depositados sob o domo dos Invalides, o novo rei exorcizava com isso o Imperador ao invés de condená-lo a um auto-de-fé. Tirando-o da tumba anônima e solitária em que intencionalmente havia sido lançado no meio do oceano, onde repousava há quase vinte anos sob a vista de pessoas que nada tinham visto de sua glória, à sombra apenas de um salgueiro que parecia reverenciá-lo quando envergado pelo vento, Napoleão, finalmente, encontraria a oportunidade de marcar definitivamente a cidade de Paris, enraizando-se nos Invalides, ainda hoje um marco de peregrinação turística.

Ele, portanto, jamais seria sepultado na Igreja de Saint-Denis, desejo este expresso em 20 de fevereiro de 1806 quando decretou a restauração da igreja, cujas criptas reconstruídas deveriam ser consagradas à sepultura dos príncipes de sua di-

\footnotetext{
${ }^{21}$ As demais informações do parágrafo anterior também foram retiradas desta mesma página. Dayot ainda dá sua opinião sobre qual projeto deveria ter coroado definitivamente o Arco, no caso o projeto de Barye e Préault que, segundo ele, “n'écraserait pas le monument, et n'en altérerait pas sensiblement la silhouette imposante”. Tratava-se de uma colossal águia de bronze, o símbolo por excelência do governo napoleônico, adequado, de acordo com ele, para arrematar dignamente um monumento que glorificava para o futuro os triunfos militares do Império.
} 
nastia (Chateaubriand 1948: II, 380). Nem mesmo o Rei de Roma, seu herdeiro nascido em 1811, seria aí inumado, tendo crescido em território austríaco como príncipe Habsburgo e falecido em 1832. Nas palavras de Chateaubriand: "l'homme creuse la tombe, Dieu en dispose". Seu território sagrado viria a ser o antigo hospital dos veteranos que servira durante seu Império de depósito para as sobras humanas dos seus planos de glória nos campos de batalha. A cerimônia do retorno das cinzas para Paris se realizaria em 15 de dezembro de 1840. Contudo, a expressão mais obscura de sua epopéia que ainda poderia guardar os Invalides dourar-se-ia de faustosas decorações nas quais Napoleão figuraria em baixos relevos alegóricos e na estátua que seria colocada no fundo da cripta.

Assim, os elementos decorativos da tumba guardam consigo uma série de simbolismos que refletem de algum modo a construção simbólica do poder napoleônico. A câmara subterrânea, onde se encontram seus despojos, é circular, lembrando a questão cósmica, de centralização, de onde tudo emana e para onde todo o universo se volta. Esta parte circular se apoia sobre doze figuras femininas aladas, em mármore branco, que envolvem com seu olhar e com sua disposição circular o túmulo do imperador. Para os mais desavisados não passariam de figuras angelicais, mas são na realidade figuras de Vitórias que evocam seus feitos gloriosos. Os dez baixos relevos, executados por Simart entre 1846 e 1852, terminam o conjunto, registrando para a posteridade os mais relevantes eventos da política interna do Império Napoleônico, no qual o imperador ainda parece presidir os trabalhos dos homens que o cercam: la Pacification des troubles civils; le Concordat; la Promulgation du Code Civil; la Creation de l'ordre de la Légion d'honneur; du Conseil d'État; de la Cour des Comptes; L'Organisation de l'Université; des grands Travaux Publics; la protection accordée au Commerce et à l'Industrie; la Centralisation Administrative.

Assim, os Invalides seriam a última grande representação napoleônica, ou melhor, seu último grande conjunto representativo. Uma espécie de resumo monumental em que se tentaria chegar a um meio-termo sobre suas mais significativas realizações em prol da formação da França Moderna. Onde a reorganização administrativa, a pacificação religiosa, o progresso industrial, a codificação de leis falariam mais alto, 
lançando às sombras o despotismo político e econômico, o controle da opinião pública e a privação das liberdades individuais. Assim, sob seu domo finalmente descansaria para sempre não apenas Napoleão Bonaparte, mas os vários "Napoleões", "Bonapartes", "anti-Napoleões" e "anti-Bonapartes", múltiplas imagens cristalizadas em torno do mesmo homem, nascidas e matizadas pelas exigências do poder e da ambição e pelas críticas feitas a eles, pelo imaginário popular e pelas glórias e tragédias militares. Ali finalmente teriam guarida todos os seus paradoxos e contradições de homem público: do "filho da Revolução" até o "sobrinho de Luís XVI".

Contudo, fica ainda a pergunta: teria Napoleão, em meio a seus projetos de reformas urbanas, transformado Paris em uma "cidade napoleônica"? Lembremos que o nome de uma cidade atrela uma série de associações, entre elas a associação, através de uma imagem mental, com um determinado local ou algum monumento. Em última instância podemos afirmar que a promoção de uma política de lugares tem em vista justamente o intuito de gerar e buscar estabelecer certas "imagens" de uma cidade. Como vimos, Napoleão trabalhou a imagem de Paris como centro de seu Império, nos moldes de uma Roma Antiga que centralizava em si um poder que se espalhava por quase todo o mundo conhecido da época.

Roma, por exemplo, apresenta uma série de associações de lugares e imagens que brotam com seu nome: as Termas, o Fórum, a Via Appia, a Coluna Trajana, o Campidoglio, o Coliseu, a Fontana di Trevi, apenas para citar os exemplos mais recorrentes. Nestas várias associações, contudo, os símbolos da Roma Imperial sempre estão presentes, fazendo com que ela permaneça, portanto, mesmo passados tantos séculos, uma cidade imperial, o que demonstra a força da intervenção que certos homens de poder da Antigüidade promoveram em sua malha urbana, marcando-a simbolicamente.

Por sua vez, Napoleão não apenas tomou de empréstimo o modelo de algumas destas intervenções (como no caso da Coluna Trajana e do Arco de Séptimo-Severo), transportando para Paris suas bem sucedidas significações simbólicas e históricas, mas aí tentou imprimir a expressão de sua força e de sua glória através do monu- 
mental, tentando fazer com que Paris passasse a ser associada ao centro do Império napoleônico e mantivesse, portanto, também a imagem de uma cidade imperial.

Os benefícios e embelezamentos promovidos sob seu governo são realmente indiscutíveis, mas como as modificações que ele promoveu não ficaram apenas no nível do bem-estar e do estético, são as ambições de seu poder que perturbam e dão margem, em especial para seus detratores, à uma série de críticas. Em Santa Helena, o próprio Las Cases registraria, em tom competitivo, o lamento do fracasso do projeto de reformas urbanas que Napoleão atribuía às conturbadas circunstâncias políticas e militares que encurtaram seus dias de homem público:

"Qualquer um tendo observado então que se o céu houvesse dado ao Imperador um reino de sessenta anos, como a Luís XIV, ele teria deixado coisas bem grandes. 'Se o céu me houvesse dado vinte anos e um pouco de distração (...) se teria buscado em vão a antiga Paris, não haveria restado qualquer vestígio, $e$ eu teria mudado a face da França” (Las Cases 1951: II, 119-20).

Vimos, portanto, vários exemplos de como Paris foi trabalhada pelos interesses e ambições napoleônicos. Mas, no flerte de aproximadamente 15 anos entre a cidade e o poder, ela acabou não adquirindo um verdadeiro aspecto "napoleônico", no sentido de seu conjunto se transformar em signo absoluto da autoridade do imperador. Não como Roma seria envolvida pela lembrança da Roma Imperial, não como Londres se renderia à Rainha Vitória, ou como Brasília evocaria Juscelino Kubitschek e Versalhes Luís XIV. Muito ainda estava por ser terminado, planejado e realizado na capital do Império e a população que se sonhara entre 2 a 4 milhões, passou apenas de pouco mais de meio milhão para 700 mil. Apesar dos monumentais elementos simbólicos ali plantados, a "Paris de Napoleão era ainda a Paris de Luís XVI com alguns monumentos a mais" (Tulard 1996: 190).

Paris até hoje se revela uma miscelânea de épocas e atividades que deixaram e deixam sua marca por toda sua extensão, mas às quais ela não se entrega exclusivamente. Portanto, ela vem resistindo com a ajuda do tempo a estas tentativas de se tornar refém de um só poder e Napoleão, na sua tentativa de tomá-la para sempre 
para si, não passou de um coadjuvante neste palco de tantos poderes. Assim, apesar de Las Cases afirmar acuradamente acerca dos trabalhos públicos promovidos pelo Imperador que "partout où l'on voyageait, au pied comme à la cime des Alpes, dans les sables de la Holande, sur les rives du Rhin, l'on retrouvait Napoléon, toujours Napoléon" (Las Cases 1951: II, 121), o ninho da águia ficaria incompleto...

\section{Referências Bibliográficas}

APOSTOLIDÈS, Jean-Marie, O Rei Máquina: espetáculo e política no tempo de Luís XIV, Rio de Janeiro: José Olympio/DF: EDUNB, 1993.

BALANDIER, Georges, O Poder em Cena, Brasília: EDUnB, 1982.b

BAUSSET, Roquefort Louis François Joseph, Barão de., Mémoires Anecdotiques sur l'Interieur du Palais et sur quelques evenements de l'Empire depuis 1805 jusqu'au $1^{\underline{\underline{e r}}}$ mai..., Bruxelas: H Tarlier, 1827.

Bíblia Sagrada, São Paulo: Ed. Ave-Maria, 1993.

BOÎME, Albert, Art in an Age of Bonapartism: 1800-1815, Chicago/Londres: The University of Chicago Press, 1993.

BOURDIEU, Pierre, O Poder Simbólico, Lisboa: Difel, 1989.

BURCHARD, John E., “The City as Symbol”, in KEPES, Gyorgy (ed.), Sign, Image, Symbol, NY: George Braziller, 1966.

BURKE, Peter, A Fabricação do Rei: a Construção da Imagem Pública de Luís XIV, Rio de Janeiro: Zahar, 1994.

CANETTI, Elias, Massa e Poder, São Paulo: Cia das Letras, 1995.

CANNADINE, David, "Contexto, Execução e Significado do Ritual: a Monarquia Britânica e a 'Invenção da Tradição', c. 1820 a 1977”' in HOBSBAWM, Eric [org.], A Invenção das Tradições, RJ: Paz e Terra, 1997.

CHASTEL, André, L'Art Français: le temps de l'éloquence (1775-1825), Paris: Flammarion, 1996.

CHATEAUBRIAND, Mémoires d'Outre Tombe, Paris: Flammarion, 1948 (5 vols).

DAYOT, Armand, Napoléon Raconté par l'Image d'après les sculpteurs, les graveurs et les peintres, Paris: Hachette, 1895.

DELÉCLUZE, E. J., Louis David: son école et son temps, Paris: Macula, 1983. 
HARTWELL, R. M., "Economic change in England and Europe, 1780-1830", in CRAWLEY, C.W. (ed.), The New Cambridge Modern History: war and peace in an age of upheaval1793-1830 (vol. IX), London/NY/Melbourne:Cambridge University Press, 1975.

HAUTECOEUR, Louis, L'Art sous la Révolution et L'Empire en France, Paris: Guy Le Prat, 1953.

HOBSBAWM, Eric, A Era das Revoluções: Europa 1789-1848, Rio de Janeiro: Paz e Terra, 1982.

HOLTMAN, Robert B., Napoleonic Propaganda, Bâton Rouge: Louisiana State University Press, 1950.

LAS CASES, Emmanuel de, Mémorial de Sainte-Hélène, Paris: Flammarion, 1951(2 vols.).

MARRINAM, Michael, Painting Politics for Louis-Philippe: Art and Ideology in Orléanist France, 1830-1848, New Haven e Londres: Yale University Press, 1988.

MARX, Karl, O 18 Brumário e Cartas a Kugelmann, Rio de Janeiro: Paz e Terra, 1977.

PIGEARD, Alain, L'Armée de Napoléon, 1800-1815: Organisation et Vie Quotidienne, Paris: Tallandier, 2000.

POMIAN, Krzystof, Collectioneurs, Amateurs et Curieux, Paris, Venise: XVI $I^{e}$ XVIII $I^{e}$ Siècle, Paris: Gallimard, 1987.

SCHWARCZ, Lilia M., As Barbas do Imperador: D. Pedro II, um monarca nos trópicos, São Paulo: Companhia das Letras, 1998.

SOUZA, Iara Lis Franco Schiavinatto Carvalho, Pátria Coroada: O Brasil como corpo político autônomo: 1780-1831, Tese de Doutorado sob a orientação de Edgar Salvadori de Decca, UNICAMP, Campinas, 1997 (2 vols.)

STENDHAL, O Vermelho e o Negro, Rio de Janeiro: Editora Globo, 1987.

TARLÉ, Eugueni. Napoleão, Lisboa: Editorial Presença, 1973 (2 vols.)

TULARD, Jean. Napoleão: o Mito do Salvador, Rio de Janeiro: Casa Jorge Editorial, 1996. Napoléon et la Noblesse d'Empire, Paris: Éditions Tallandier, 2001.

WARNKE, Martin, L'Artiste et la Cour: aux origines de l'artiste moderne, Paris: Ed. de la Maison des Sciences de l'Homme, 1989.

\section{Índice de llustrações}

Fig. 1 - Rua de Rivoli (Paris), por Percier e Fontaine (1802-1808), p. 5 (in Chastel 1996: 246)

Fig. 2 - Fachada da Église de Madeleine, Vignon (1806), p. 6 (Id. : 17) 
Fig. 3 - Estátuas da Coluna Vendôme por Chaudet e Seurre (Paris, abril de 1814), p. 10 (in Dayot 1895: 155)

Fig. 4 - Arco do Triunfo do Carrossel (Paris), por Percier e Fontaine (1806-1808), p. 14 (in Chastel 1996: 239)

Fig. 5 - Arco do Triunfo da Estrela (Paris), por Chalgrin (1806-1836), p. 15 (Id.: 237)

Fig. 6 - "Le Triomphe de Napoléon" (detalhe do Arco do Triunfo da Estrela, Paris), por Cortot, p. 21 (in Dayot 1895: 213)

Fig. 7 - Fontaine du Fellah (rua de Sèvres, Paris), Bralle e Beauvallet (1806-1809), p. 26 (in Chastel 1996: 103) 